

\section{DISCLAIMER}

This report was prepared as an account of work sponsored by an agency of the United States Government. Neither the United States Government nor any agency Thereof, nor any of their employees, makes any warranty, express or implied, or assumes any legal liability or responsibility for the accuracy, completeness, or usefulness of any information, apparatus, product, or process disclosed, or represents that its use would not infringe privately owned rights. Reference herein to any specific commercial product, process, or service by trade name, trademark, manufacturer, or otherwise does not necessarily constitute or imply its endorsement, recommendation, or favoring by the United States Government or any agency thereof. The views and opinions of authors expressed herein do not necessarily state or reflect those of the United States Government or any agency thereof. 


\section{DISCLAIMER}

Portions of this document may be illegible in electronic image products. Images are produced from the best available original document. 
An Affirmative Action/Equal Opportunity Employer

This work was supported by the US Department of Energy, Division of Geothermal Energy, Federal Hot Dry Rock Program.

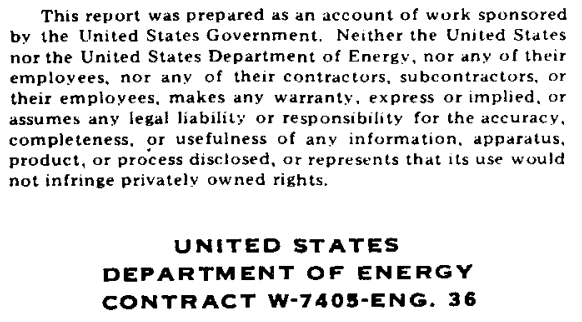


LA.7603-MS

Informal Report

UC-66f

Issued: January 1979

\title{
Electricity from Hot Dry Rock Geothermal Energy: Technical and Economic Issues
}

\author{
Jefferson W. Tester \\ Glenn E. Morris \\ Ronald G. Cummings* \\ Robert L. Bivins
}

${ }^{*}$ Visiting Staff Member. Department of Economics, University of New Mexico, Albuquerque, NM 87106.

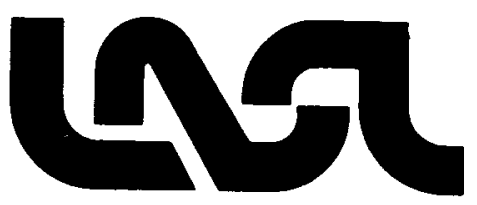




\title{
ELECTRICITY FROM HOT DRY ROCK GEOTHERMAL ENERGY: TECHNICAL AND ECONOMIC ISSUES
}

\author{
by \\ Jefferson W. Tester, Glenn E. Morris, \\ Ronald G. Cummings, and Robert L. Bivins
}

\begin{abstract}
Extraction of energy from hot dry rock would make available a nearly unlimited energy source. Some of the technical problems and possible economic tradeoffs involved in a power generating system are examined and possible solutions proposed. An intertemporal optimization computer model of electricity production from a hot dry rock geothermal source has been constructed. The effects of reservoir degradation, variable fluid flow rate, and drilling operations are examined to determine optimal strategies for reservoir management and necessary conditions for economic feasibility.
\end{abstract}

\section{INTRODUCTION}

There are a number of concepts for extracting energy from hot dry rock (HDR) geothermal resources being explored by the Department of Energy (DOE) and the Los Alamos Scientific Laboratory (LASL), in particular. The economic feasibility of HDR as a source of energy for commercial electricity production throughout the United States is also being assessed.

The technical feasibility of many facets of HDR systems has been demonstrated in the first field experiments being conducted by the Los Alamos Scientific Laboratory at the Fenton Hill site in the Jemez Mountains of New Mexico. ${ }^{1-8}$ At the present time, a reservoir has been created by hydraulic fracturing in low-permeability crystalline basement rock at $\sim 185^{\circ} \mathrm{C}$. The reservoir has been flow tested for 75 days at an energy extraction rate of approximately 5 $\mathrm{MW}(\mathrm{t})$. Although the present reservoir has only 8000 $\mathrm{m}^{2}$ and is to small to be of commercial value, plans are under way to enlarge this to a $50-\mathrm{MW}(\mathrm{t})$ capacity with an extended lifetime.

The HDR resource is defined in Sec. 2 and distinctions are made between two major rock formation types: high and low permeability. Some of the alternative HDR reservoir configurations, which might be employed to extract energy from these resource types are then discussed.

A special effort is made to highlight the wide range of development options available, for HDR systems. The initial depth of the injection and recovery wells, the fluid flow rate, the timing and nature of redrilling activities, and the size and configuration of the fracture system are all, to a significant extent, independently specified by design in HDR systems. Our purpose is to emphasize that the selection of particular reservoir design and operating conditions will determine feasibility of HDR technology under an appropriate set of financial, regulatory, and institutional constraints and assumptions. 
The best economic choices will, of course, depend on the-overall technical performance of the various HDR reservoir systems. Of particular concern are the HDR reservoir's lifetime and capacity, which are discussed in detail in Sec. 3. Also included is background information on how reservoir performance features are incorporated into the evaluation model.

The ultimate objective of this report is to evaluate HDR technology as a source of energy for the production of electric power. Consequently, we reviewed electric power plant options and anticipated performance using relatively lowtemperature fluids $\left(100-300^{\circ} \mathrm{C}\right)$, which may be produced by typical HDR reservoirs. Environmental concerns are covered in Sec. 5.

The commercial feasibility, in Sec. 6, addresses the size and quality of the resource in the U.S., the important engineering issues, and the important economic variables and relationships. The latter discussion provides a detailed description of the methodology used to combine the formation properties and engineering data with economic factors to yield an evaluation model for HDR-produced electricity.

The operation of the evaluation model is described further in Sec. 7. It provides an intertemporal optimization approach using a dynamic programming algorithm. The control variables in this model are well flow rates and drilling activity, and the state variables are reservoir depth and temperature. This formulation allows the model both to select the optimal management strategy for the system subject to specified initial conditions and assumptions and to determine if this strategy results in electricity that could be priced competitively.

The results of the model for a given set of geologic, engineering, and economic conditions are discussed in Sec. 8. The implications of different geothermal temperature gradients, maximum fluid flow rates, interest rates, rates of return, and electricity prices for commercial feasibility of HDR-produced electricity are examined. These results, in conjunction with optimal resource management strategies, suggest grounds for guarded optimism for the future of HDR-produced electricity in the U.S., if reservoir temperature loss can be satisfactorily controlled at acceptable energy extraction rates.

\section{ENERGY EXTRACTION CONCEPTS}

To understand the economics of hot dry rock geothermal energy utilization, one must study several technical aspects of the reservoir and surface systems. Geothermal power plants now operating throughout the world typically involve an underground reservoir containing natural steam and/or hot water which is brought to the surface by way of a set of drilled wells. Geothermal fluid flows under artesian pressure or is pumped through a collection or a gathering system of pipes to a centrally located power plant, which may produce electricity, process heat, or both. Often reinjection wells are used to return the cooled fluid to the formation. The main feature that distinguishes a HDR system from these natural hydrothermal systems is the absence of a sufficient amount of spontaneously produced indigenous reservoir fluid.

This important feature of the HDR resource provides a degree of flexibility that is inherently absent from natural hydrothermal reservoirs. Namely, HDR reservoir temperatures may be selected by drilling to a specified depth determined by the geothermal temperature gradient. If the reservoir has a short lifetime, remedial treatment of an HDR reservoir is possible by redrilling to a hotter region of rock. In the hydrothermal case, the reservoir conditions, including in situ fluid temperature, pressure and composition, and formation permeability and porosity are determined by existing natural conditions in that region. Therefore, the unique relationship between reservoir temperature and depth in HDR systems provides a framework for exploring the economic dimensions of deeper, hotter, more costly wells vs shallower, cooler, less expensive wells balanced against the value of the product; that is, electricity or heat or both.

HDR reservoirs may exist in formations having permeabilities ranging from very low $(<1$ microdarcy) to high ( $>10$ millidarcy), in which the rock itself is hot enough to be considered useful for energy extraction. Depending on the end use, temperatures may be as low as $100^{\circ} \mathrm{C}$ for space heating purposes or higher than $300^{\circ} \mathrm{C}$ for producing electricity. In all cases, an HDR formation requires artificial stimulation to create either sufficient in situ permeability or bounded flow paths so heat may be removed by circulation of a suitable fluid over the surfaces of the rock. 
Reasonable rates of energy extraction and sufficient reservoir lifetimes ( $\sim 20 \mathrm{yr}$ or greater) from HDR systems may be achieved using two fundamental approaches to mining the heat. First, if in situ formation permeabilities are low, an artificial system must be created to expose a circulating fluid (for example, water) to the hot rock by creating high-conductance flow passages with a sufficiently large heat-transfer surface area. In this case, recovery of most of the injected fluid may be achieved quite easily by taking advantage of the natural containment provided by the low permeability of the formation. ${ }^{1,2}$ But if the permeability is high, the techniques to contain and recover the fluid and to ensure uniform fluid contact with the hot rock surface are more demanding. The same approaches used for recovery of gas and oil by water drive or flooding methods may be quite applicable to HDR problems. Both production- and injection-well networks would be arranged so that fluid loss to surrounding permeable formations at the perimeter of the developed geothermal field is minimal.

Several possible concepts for low-permeability formations are shown in Fig. 1. These concepts are now being considered by LASL. ${ }^{1-4}$ The first concept is a single vertical hydraulic fracture produced from one wellbore by fluid pressurization exceeding the confined strength of the rock (Fig. 1A). The required surface areas for heat extraction are created by continued high-pressure injection of fluid. The downhole system is completed by directionally drilling a second wellbore to intersect the fractured region sufficiently separated from the first wellbore to avoid flow short-circuiting. Pressurized working fluid is then circulated down one hole through the fractured region to remove energy from the rock and is recovered in a second hole. Energy is extracted at the surface using heat exchangers, and the cooled fluid is reinjected to complete a closed cycle. Even with low permeabilities, some makeup water is required. Because reservoirs of this type will most likely be formed at depths sufficient to ensure that the least principal earth stress is in the horizontal plane, the hydraulic fracture should have a near-vertical orientation. Assuming that the stress field is uniform and the physical strength properties of the formation are approximately isotropic and homogeneous, an ideal fracture of circular shape with an elliptical cross section should be formed..$^{1,8,6-7}$

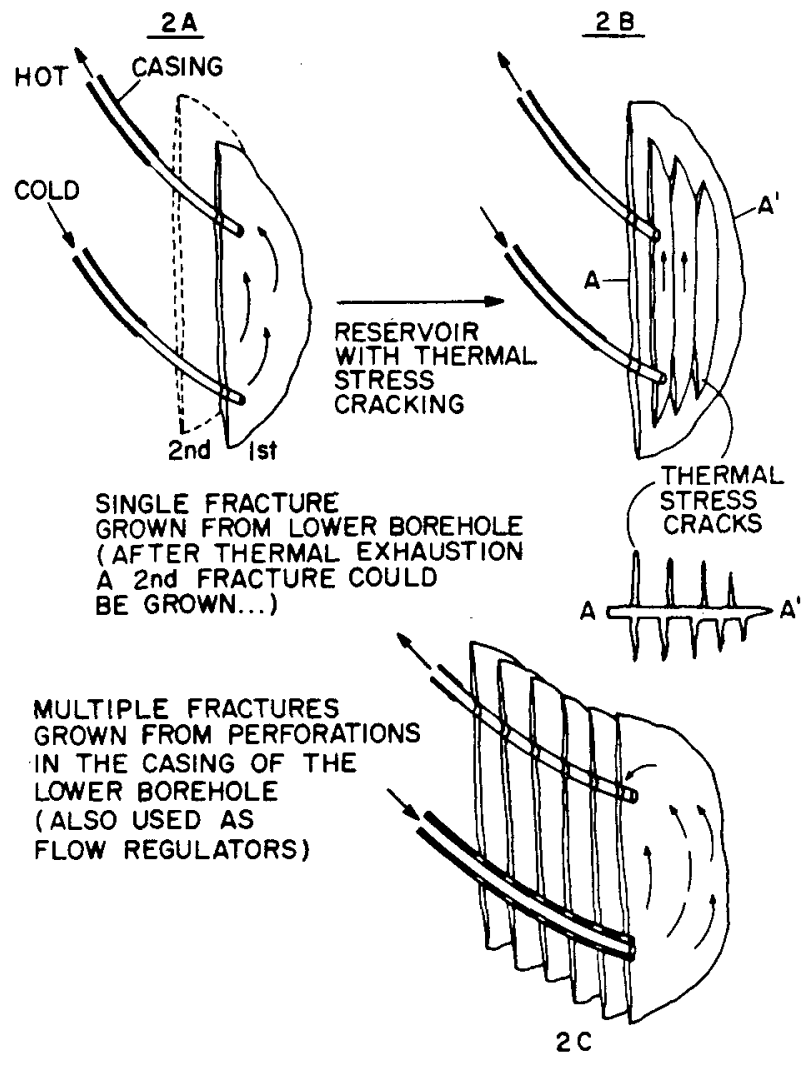

Fig. 1.

Single- and multiple-fracture concepts applicable to low-permeability formations. Symmetrical views of hydraulic fracture halfplanes are shown in Fig. 2.

Fracture radii will be typically $100 \mathrm{~m}$ or greater with widths of a few millimeters in cross section. Because the inherently low thermal conductivity of the rock quickly controls the rate of heat transfer to the circulating fluid, large fracture surface areas are required. For optimum performance of a reservoir of this type, the fluid should contact as much of the fracture surface as possible. Fracture conductances or permeabilities for self- or pressure-propped fractures should be sufficiently high to permit buoyant circulation across the faces of the fracture between the inlet and outlet points of the system as shown in Fig. 1.

If thermal exhaustion of the reservoir occurs because of insufficient surface area, remedial stimulation treatment is possible. ${ }^{s-14}$ By proper orientation of the boreholes in a parallel, inclined arrangement as shown in Fig. 1A, additional fracturing might be used to provide new surface area in a 
hot region of rock. Sidetracking of the original wellbores to a new region and refracturing might also be an attractive method of restimulation. Removal of heat from the vicinity of the fracture surface may introduce sufficient thermal contraction and induced stresses to cause additional cracking of the rock. If these thermal stress cracks propagate in such a way as to provide accessible flow channels for the circulating fluid as shown in Fig. 1B, the performance and lifetime of the reservoir will be substantially enhanced. Thermal stress cracking of this type increases the heat transfer efficiency by forming an extended surface penetrating into the hotter regions of the formation. As McFarland and Murphy ${ }^{5}$ point out, even without thermal stress cracking, the thermal contraction of the rock will increase the fracture gap width, thus allowing buoyancy effects to sweep fluid more uniformly over the available fracture surface area. ${ }^{2}$

If thermal stress cracking does not occur in this manner and if large $\left(\sim 1 \times 10^{8}-\mathrm{m}^{2}\right)$ stable fracture areas cannot be produced, multiple fractures in inclined boreholes may be the alternative, which has been suggested by Raleigh et al. ${ }^{7}$ and R. M. Potter of LASL and analyzed by Gringarten et al. ${ }^{\mathrm{B}}$ and Wunder and Murphy. ${ }^{12}$ This may provide a tractable technique for generating sufficient surface area to maintain reservoir lifetime (see Fig. 1C).

For high-permeability formations, two-spot, fivespot, and similar peripheral flooding techniques using water drive are possible. ${ }^{8}$ Figure 2 shows another concept consisting of three parallel fractures of similar area, which minimizes water losses while maintaining uniform contact between the circulating fluid and reservoir rock. The centrally located fracture serves as the fluid injection surface while the two outside fractures receive fluid by permeation through the rock. If nearly uniform plug flow can be maintained in such a system, reservoir lifetime will be determined by the heat content of the contained rock volume.

\section{RESERVOIR PERFORMANCE}

The temperature changes that may occur in the reservoir output fluid, as well as the rate of power production over the 20- to 40-yr lifetime of an HDR power plant, can be crucial in developing an optimal strategy for reservoir management. The most desirable approach is to maintain a constant output

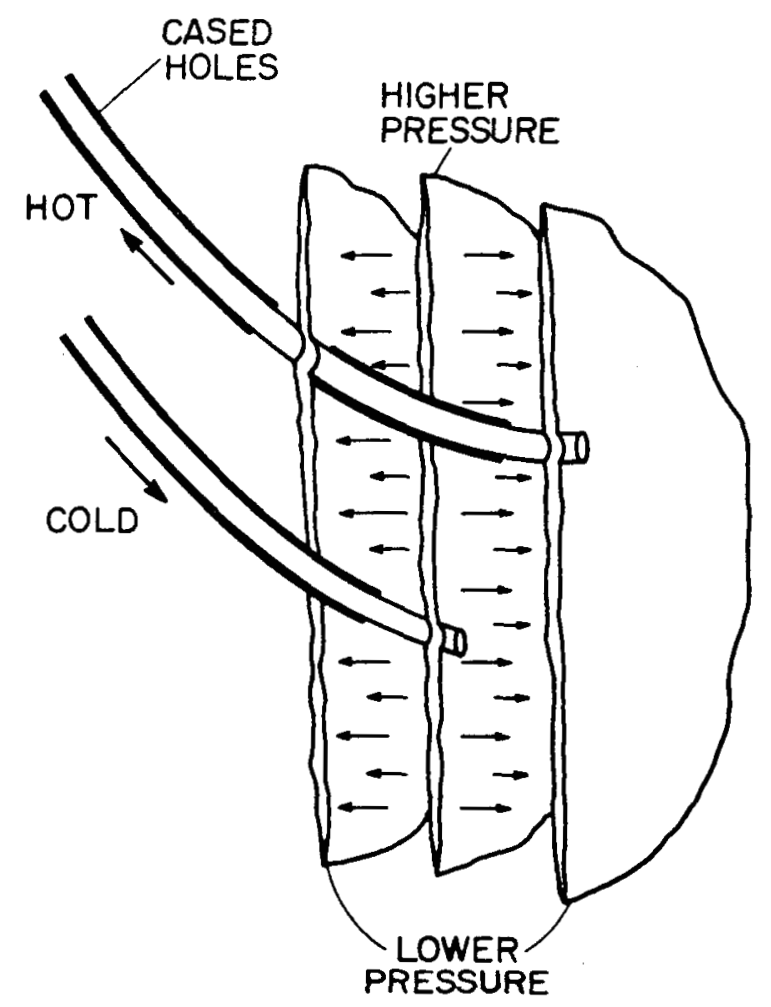

Fig. 2.

Double parallel fracture water-drive concept for extraction of HDR energy. Applicable to high-permeability formations. Fracture planes divided at a vertical axis of symmetry.

temperature while maximizing the mass flow rate of fluid through the reservoir. This will not be possible because any finite-sized system will have a finite rate of drawdown. The energy drawdown rate for a fractured HDR reservoir with low formation permeability will depend on the following items:

- accessible fracture surface area A,

- mass flow rate $\dot{m}_{w}$,

- distribution of fluid across the fractured surface, and

- thermal properties of the rock (density, heat capacity, and conductivity).

A simplified approach to estimating reservoir performance assumes that a certain fraction $\eta$ of the recoverable power, corresponding to uniform flow across the face of an ideal plane fracture, could be extracted. By solving the transient problem of onedimensional heat conduction from the rock into the fracture face, the recoverable power $\mathrm{P}(\mathrm{t})$, in $\mathrm{J} / \mathrm{s}$, for uniform flow can be expressed in this manner. ${ }^{8,12}$ 


$$
P(t)=n \dot{m}_{w} C_{w}\left(T_{i}-T_{\min }\right) \operatorname{erf}\left(\sqrt{\frac{(\lambda \rho C)_{r}}{t}} \frac{\pi R^{2}}{\dot{m}_{w} C_{w}}\right) \text {, }
$$

where

$$
\begin{array}{rl}
\mathrm{A}=\pi \mathrm{R}^{2}= & \text { area of one face of the fracture in } \\
& \text { square meters, } \\
= & \text { heat capacity of water, which is } 4200 \\
\mathrm{C}_{\mathrm{w}} & \mathrm{J} / \mathrm{kg} \mathrm{K}, \\
= & \text { heat capacity of granite, which is } 1000 \\
& \mathrm{~J} / \mathrm{kg} \mathrm{K}, \\
\mathrm{C}_{\mathrm{r}} & \text { water flow rate through the fracture in } \\
& \text { kilograms per second, } \\
\dot{\mathrm{m}}_{\mathrm{w}} \quad & \text { fracture radius in meters, } \\
\mathrm{R} & =\text { time in seconds, } \\
\mathrm{t} & \text { mean initial rock temperature in } \\
& \text { degrees Celsius, } \\
\mathrm{T}_{1} \quad & \text { fluid reinjection temperature in } \\
& \text { degrees Celsius, } \\
\mathrm{T}_{\mathrm{m} 1 \mathrm{n}} \quad= & \text { thermal conductivity of granite, which } \\
\lambda_{\mathrm{r}} & \text { is } 3.0 \mathrm{~W} / \mathrm{m} \mathrm{K}, \text { and } \\
\rho_{\mathrm{r}} & \text { rock density, which is } ~ 2500 \mathrm{~kg} / \mathrm{m}^{3} .
\end{array}
$$

McFarland and Murphy compared $\mathrm{P}(\mathrm{t})$ to estimated values that account for nonuniform flow across the accessible fracture area. ${ }^{5}$ Fluid buoyancy and convection effects within an ideal fracture, as well as transient conduction of heat through the surrounding rock, are treated in a numerical solution of the four coupled two-dimensional, nonlinear partial differential equations describing continuity, fluid momentum, and rock and fluid energy balances. Depending on the location and separation of fluid injection and recovery points within the fracture and the internal fracture permeability (gap width vs radius), the recovered fraction of power $\eta$ may vary from 0.4 to 0.9 , depending on the degree of buoyant circulation through the fracture (see Figs. 1 and 3). The computer-simulated flow contours presented in Fig. 4 compare flow in a relatively high impedance fracture with suppressed buoyancy effects vs a low impedance flow with active buoyancy effects.

Equation (1) shows that the relative power $[P(t) / P(t=0)]$ depends directly on the error function of $\left[\mathrm{K}\left(\mathrm{R}^{2}\right) /\left(\dot{\mathrm{m}}_{\mathrm{w}} \sqrt{\mathrm{t}}\right)\right]$ for constant rock and fluid properties where $\left.\mathrm{K}=\pi \sqrt{\left[(\lambda \rho \mathrm{C})_{\mathrm{r}}\right] /\left[\mathrm{C}_{\mathrm{w}}{ }^{2}\right.}\right]$. Therefore, reasonably accurate predictions of reservoir lifetime

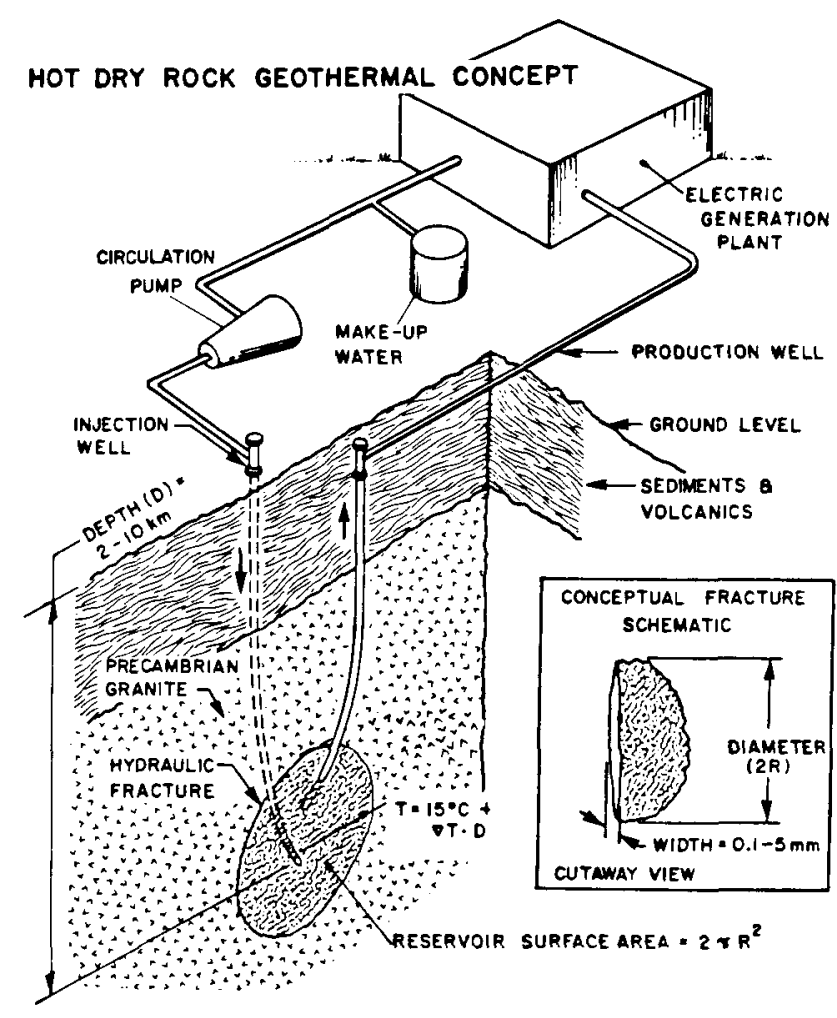

Fig. 3.

Schematic representation of a conceptual Hot Dry Rock system in low-permeability rock.

can be made for specified ideal fracture sizes and flow rates. Figure 5 presents parametric results for the thermal power ratio vs time $t$ using different values of $\dot{m}_{w} / R^{2}$ to generate a family of curves for a single fracture reservoir in granite.

For cases where large stable fractures cannot be produced, smaller multiple parallel fractures may be used to generate the required surface area to maintain an acceptable resevoir lifetime. Wunder and Murphy ${ }^{12}$ and Gringarten et al. ${ }^{8}$ have examined the heat extraction capacity of multiple fractured systems showing the effects of variable fracture number and spacing. Because of the low thermal conductivity of granite, the penetration depth of the thermal wave is small, and fractures spaced $20-50 \mathrm{~m}$ apart avoid thermal interference over a $20-$ to $30-\mathrm{yr}$ period. Thus the thermal drawdown will resemble that for a single fracture as shown in Fig. 5. Wunder and Murphy also treat an intermediate case with 1$\mathrm{m}$ fracture spacing where there is a strong superposition of heat flow between fractures and a very different drawdown behavior. In the extreme case of 


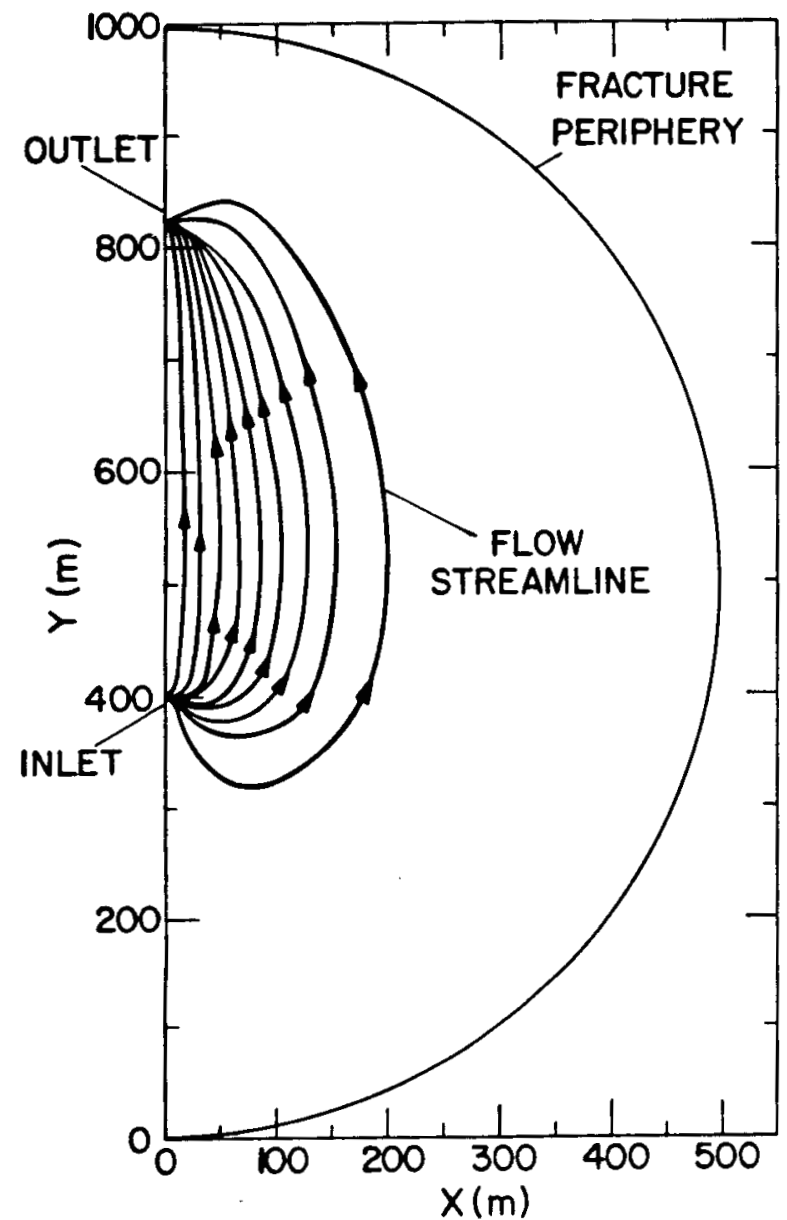

a. With thermal contraction buoyancy suppressed, $\rho=45 \mathrm{MW}(\mathrm{t})$ with $\eta=0.42$.

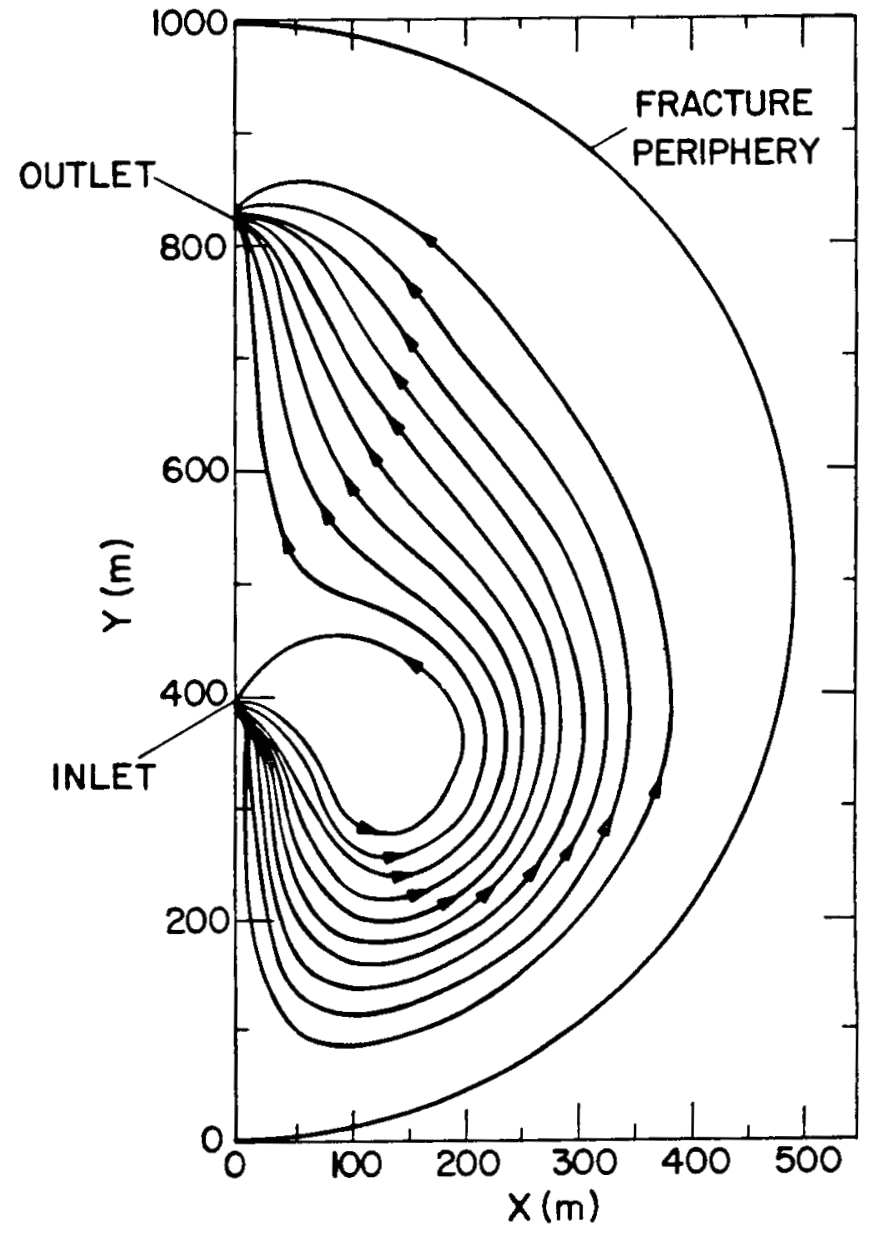

b. With thermal contraction buoyancy active, $\rho$ $=99 \mathrm{MW}(\mathrm{t})$ with $\eta=0.88$.

Fig. 4.

Flow contours simulated by the McFarland-Murphy model $l^{5}$ of heat transfer in an idealized plane circular crack of 500-m radius and elliptical cross section. Streamlines shown contain approximately $10 \%$ of the total $144-\mathrm{kg} / \mathrm{s}$ flow. An initial mean rock temperature of $250^{\circ} \mathrm{C}$ was used with a gradient of $50^{\circ} \mathrm{C} / \mathrm{km}$.

completely rubblized rock, a square temperature wave would propagate through the reservoir showing a breakthrough effect analogous to that anticipated for waterdrive-type systems as shown in Fig. 2. In the case of Fig. 2, the lifetime of the reservoir $\bar{\tau}$ would be given by

$\bar{\tau}=\frac{\rho_{r} C_{r} A L(1-\theta)+\frac{\rho_{w} C_{w}}{\rho_{r} C_{r}} \theta}{\dot{m}_{w} C_{w}}$, where $\mathrm{L}=$ separation distance between fractures $\mathrm{m}$, and $\theta=$ porosity.

None of the performance analyses presented so far include any beneficial effects caused by thermal stress cracking. Harlow and Pracht, ${ }^{6}$ using a simplified model, demonstrated that substantial enhancement of reservoir performance could be anticipated. The mechanisms associated with thermal stress cracking are extraordinarily complex and not well understood even under well-defined laboratory 


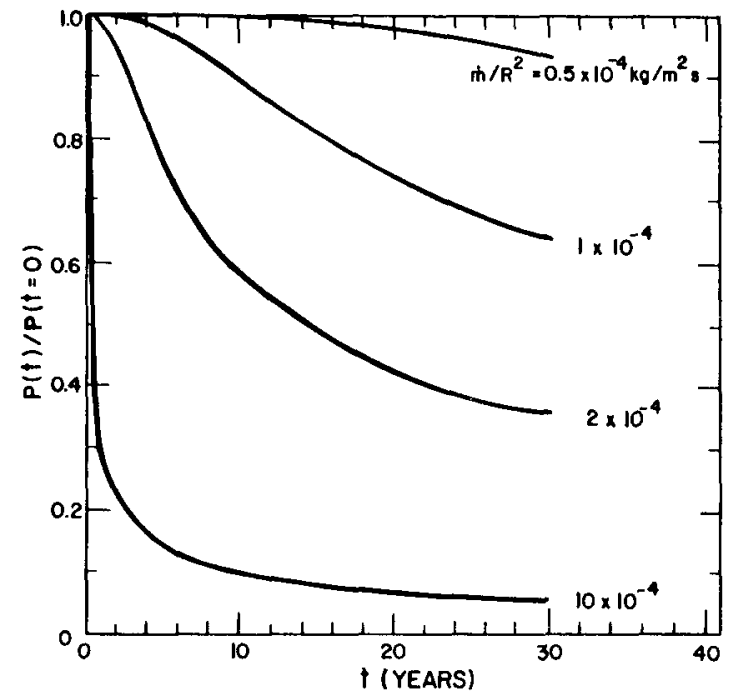

Fig. 5.

Parametric power drawdown curves for a single fracture with no thermal stress cracking, $\eta=$ 0.9 .

conditions. Consequently, LASL will use its reservoir at the Fenton Hill field test site as a way of identifying in situ thermal stress effects."

Theoretical work on thermal stress cracking has continued over the past years at Northwestern University by S. Nemat-Nasser, L. M. Keer, and associates $^{9-11}$ and at Los Alamos by H. D. Murphy, D. W. Brown, and others. ${ }^{\mathrm{s}, 14}$ Several interesting ideas not apparent in earlier work have resulted. Heat extraction from fractured reservoirs may introduce secondary thermal cracks that grow in a discrete manner with a shallow, closely spaced distribution of cracks eventually coalescing into a deeper, more widely spaced network of cracks. These larger cracks will have sufficient apertures to permit convective circulation of fluid within the thermal crack. This, of course, will have an "autocatalytic" effect and greatly increases the heat removal rate, thereby accelerating the propagation of the cracks. Eventually, another set of orthogonal cracks may nucleate along the surface of these initial cracks. These effects will all eventually lead to thermal stress enhancement of the reservoir, but in order to predict the required cooling for crack initiation and the resulting growth rates of these thermal cracks, an accurate knowledge of the in situ heterogeneities and stresses will be required.

\section{ELECTRIC POWER GENERATION FROM HO'T DRY ROCK SYSTEMS}

Using a geothermal resource to supply heat to an electric power generating cycle frequently involves a different set of design criteria than conventional fossile-fuel-fired or nuclear generating cycles. Because conversion efficiencies range from 8 to $20 \%$ for geothermal resource temperatures of 100 to $300^{\circ} \mathrm{C}$, and because drilling-related costs frequently represent more than $60 \%$ of the total capital investment in the power plant, a premium is placed on designing and operating conversion systems near their thermodynamic limiting efficiencies. The following discussion summarizes the main features of a study of geothermal power conversion systems made by Milora and Tester, ${ }^{18}$ where the main effort was directed toward developing thermodynamic and economic design criteria applicable to generating electric power from low-temperature geothermal resources.

Rankine or similar cycles have been used for power production with water as the working fluid, particularly where natural steam is available. For liquid-dominated systems, steam vapor can be created by flashing the geothermal fluid at the surface to a lower pressure. Then, the saturated steam phase can be used to drive a turbogenerator unit, with the unflashed liquid fraction either reinjected or discarded. Binary fluid cycles employing nonaqueous working fluids are alternatives to singleand multiple-flashing systems currently in use in various parts of the world (for example, Cerro Prieto, Mexico, and Wairakei, New Zealand) ${ }^{16}$ Binary fluid cycles involve a primary heat exchange step where heat from the geothermal fluid is transferred to another working fluid, which expands through a turbogenerator and then passes to a condenser/desuperheater for heat rejection to the environment. The cycle is completed by pumping the fluid up to the maximum cycle operating pressure.

Nonaqueous working fluids with large, lowtemperature vapor densities would require smaller turbines than the low-pressure steam turbines employed in flashing systems of the same power output. This is particularly true where heat rejection conditions of $30^{\circ} \mathrm{C}$ or less exist. Flashing cycles are, of course, simpler in that they do not require a primary heat exchanger. 
Seven working fluids in addition to water were examined. Refrigerants R-22 $\left(\mathrm{CHC}_{1} \mathrm{~F}_{2}\right), \mathrm{R}-600 \mathrm{a}$ (isobutane, i- $\left.\mathrm{C}_{4} \mathrm{H}_{10}\right)$, R-32 $\left(\mathrm{CH}_{2} \mathrm{~F}_{2}\right), \mathrm{R}-717$ (ammonia, $\left.\mathrm{NH}_{3}\right)$, RC-318 $\left(\mathrm{C}_{4} \mathrm{~F}_{8}\right), \mathrm{R}-114\left(\mathrm{C}_{2} \mathrm{Cl}_{2} \mathrm{~F}_{4}\right)$, and R-115 $\left(\mathrm{C}_{2} \mathrm{ClF}_{5}\right)$ were selected because they provided a range of critical temperatures and pressures, and molecular weights. Data on the thermodynamic properties of proposed fluids are required to calculate cycle performance. ${ }^{13}$ All of these components have relatively high vapor densities compared to water at temperatures as low as $20^{\circ} \mathrm{C}$.

Detailed calculations of binary fluid Rankinecycle configurations were performed to examine the effects of cycle operating pressure, heat rejection temperature, temperature differences in the primary heat exchanger and condenser, turbine and pump efficiencies, and fluid temperature. In each case a utilization efficiency $\eta_{\mathrm{u}}$ was determined, which related the actual electrical work produced by the cycle to the maximum work (or availability) possible with specified geothermal source and heat rejection temperatures. Comparisons were also made with single-and multistage steam flashing cycles.

However, binary fluid turbogenerators have not as yet been placed in commercial geothermal operation with units above $\sim 1-\mathrm{MW}(\mathrm{e})$ capacity, even though smaller units have been operated. Power generation from geothermal, solar, and waste heat sources using nonaqueous working fluids will continue to evolve in the coming years under private and public support, and it is not anticipated that any serious problems will exist in scaling up from the existing $60-\mathrm{kW}(\mathrm{e})$ to 1-MW(e) units ćurrently available.

For any given working fluid, there is an optimum set of operating conditions yielding a maximum $\eta_{\mathrm{u}}$ for particular geothermal fluid and heat rejection temperatures and turbine and pump efficiencies. In screening potential working fluids, some knowledge of the magnitude of $\eta_{\mathrm{u}}$ and how it changes would be useful. Computer optimizations for the seven working fluids studied were conducted for geothermal fluid temperatures ranging from 100 to $300^{\circ} \mathrm{C}$, as shown in Fig. 6 (see Ref. 13 for details). At each point, cycle pressures were varied until an optimum was determined at that temperature. One observes a characteristic maximum $\eta_{u}$ at a particular resource temperature that is different for each fluid but generally in the range of 60 to $70 \%$; assuming a minimum approach (pinch point) temperature of

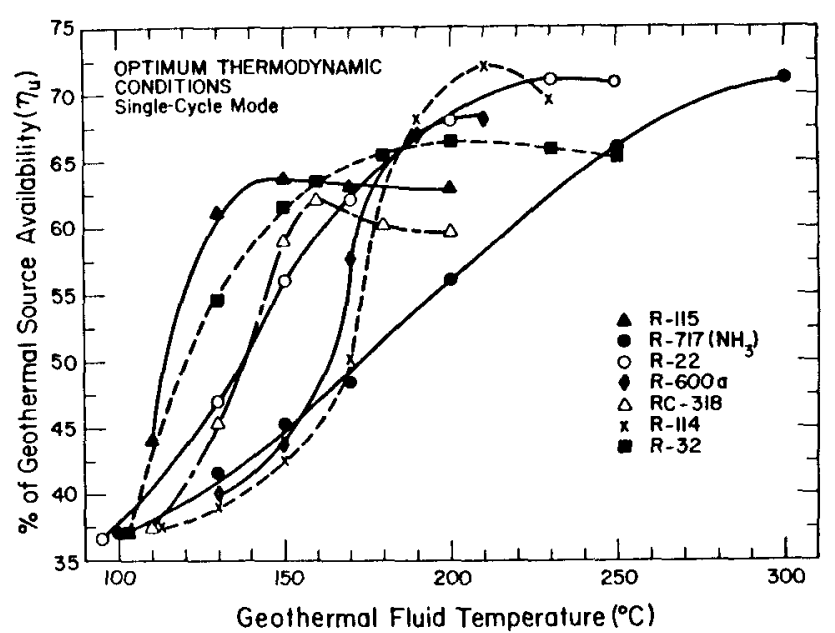

Fig. 6.

Geothermal utilization efficiency $\eta_{\mu}$ for binary fluid cycle configurations as a function of geothermal fluid temperature for optimum thermodynamic operating conditions. ${ }^{18}$

$10^{\circ} \mathrm{C}$ between the countercurrently flowing geother$\mathrm{mal}$ and cycle working fluids in the primary heat exchanger, an $85 \%$ dry turbine stage efficiency, and an $80 \%$ feed pump efficiency. Component efficiencies of this magnitude have been achieved in similarly sized commercial units. The thermodynamic code for cycle analysis was used in estimating surface conversion plant costs as discussed in Sec. 6 .

\section{ENVIRONMENTAL CONCERNS}

In both an HDR system and a natural hydrothermal system, the entire fuel cycle is located at the power generating station. This contrasts quite markedly with other energy sources such as oil, gas, coal, and nuclear. Liquid and gaseous effluents should be almost nonexistent for HDR systems because they are intended to operate as a closed cycle (see Fig. 3). If water chemistry problems such as corrosion or scaling exist, some treatment may be required and solid effluents (removed deposits) may result; but none of this should present a serious environmental impact. ${ }^{26}$ For example, a 100-MW(e) plant might have a solids output of 1-10 tons per day of silica or calcium carbonate-type material. 
Although water loss through permeation in the reservoir formation may be a strong economic factor in arid regions particularly, aquifer contamination is highly unlikely due to the extreme depths of the fracture system (typically $3-5 \mathrm{~km}$ ). Probably the major concern with HDR systems involving pressurized fractures is the level of induced seismicity caused by injected fluids. Results from the first extensive test at Fenton Hill ${ }^{4}$ have shown that no seismic events could be detected by the surface seismic arrays surrounding the experiment with a detection threshold of Richter 0.5. In addition, because of the inherently stable nature of thermal crack propagation in rock of this type that is contained in a large earth stress field, we do not anticipate any serious effects of seismicity from thermal cracking. Furthermore, once the system is shut down, the reheating of cooled sections will occur in a quiescent fashion essentially by thermal conduction.

\section{COMMERCIAL FEASIBILITY ISSUES}

\subsection{Size and Quality of the Resource}

There are two critical questions relating to the nature of the HDR resource itself: How is it defined? and How is it distributed throughout the United States? Both have potential economic impact on drilling and reservoir development costs. Using the approaches suggested by the United States Geological Survey (USGS), ${ }^{17}$ Diment et al., ${ }^{18}$ and McGetchin, ${ }^{19}$ one can expand the hydrothermal resource base to include HDR energy stored as heat above $150^{\circ} \mathrm{C}$ in the crustal rock beneath the U.S. (including Alaska and Hawaii) at depths less than $10 \mathrm{~km}$ that can be drilled with presently available technology. A minimum usable temperature is assumed to be $50^{\circ} \mathrm{C}$. Using a conservative average geothermal temperature gradient of $22^{\circ} \mathrm{C} / \mathrm{km}$, a staggering $13 \times 10^{24} \mathrm{~J}(13000000$ quads $)$ is calculated as compared to a present annual U.S. consumption of approximately 80 quads. However, this is total energy in place, not the amount that can be recovered. If we assume for the moment that only a small fraction $(\sim 0.2 \%)$ of the HDR resource base is technically recoverable, this would be comparable to the estimated resource base of all the coal remaining in the U.S.

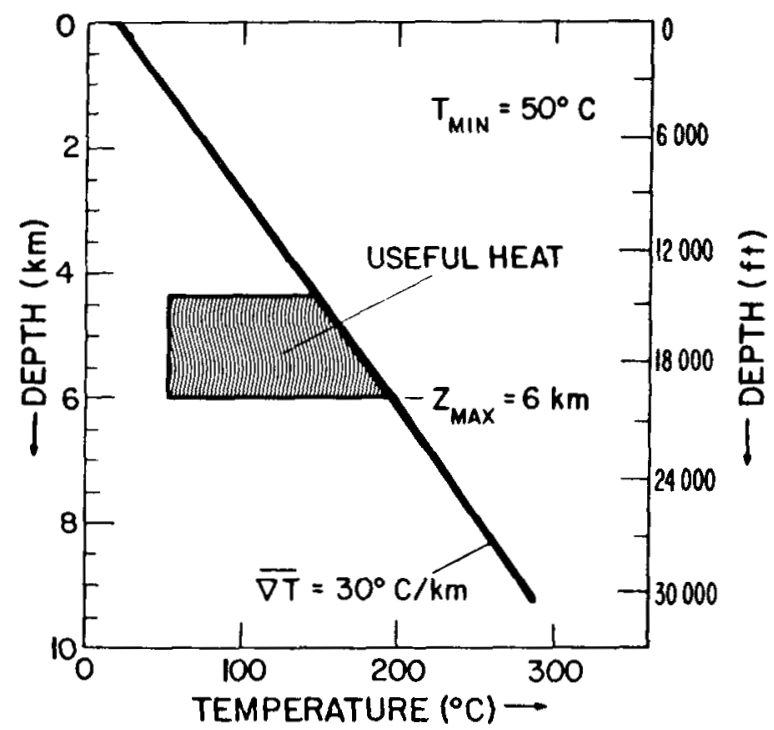

Fig. 7.

Potentially useful heat for electric power generation with a 6-km maximum drilling depth, with an average temperature gradient of $30^{\circ} \mathrm{C} / \mathrm{km}$ and constant heat flux assumed. A constant surface temperature of $15^{\circ} \mathrm{C}$ is assumed.

The potentially useful heat contained in an HDR resource can be illustrated using a plot of rock temperature vs depth. For example, Fig. 7 characterizes usable heat for electric power generation for a mean gradient of $30^{\circ} \mathrm{C} / \mathrm{km}$ considering only heat initially above $150^{\circ} \mathrm{C}(4.5 \mathrm{~km})$ to a minimum usable temperature of $50^{\circ} \mathrm{C}$. A maximum reservoir temperature of $195^{\circ} \mathrm{C}$ is then defined by an assumed 6-km maximum economic drilling depth because under current economic conditions, drilling to $10 \mathrm{~km}$ would not be commercially feasible.

Having established the magnitude of the HDR resource base in general terms, the next step is to consider its distribution throughout the U.S. in terms of grade and formation type. Locating highgrade resources (high-gradient areas) is of particular importance. Because drilling costs increase exponentially with depth, a variation in gradient from 20 to 30 or $40^{\circ} \mathrm{C} / \mathrm{km}$ has an extraordinary impact on reservoir development costs.

Two general heat source categories of HDR exist: igneous-related crustal heat caused by magma bodies, and conductional and radiogenic heat from 
the earth's interior. ${ }^{17,20}$ Smith and Shaw ${ }^{20}$ estimate that molten and crystallized igneous systems to depths of $10 \mathrm{~km}$ in the conterminous U.S. contribute about $105 \times 10^{21} \mathrm{~J}$ (105000 quads) to the HDR resource base. McGetchin ${ }^{18}$ claims that in this category $74 \times 10^{21} \mathrm{~J}$ (74000 quads) exist as heat over $150^{\circ} \mathrm{C}$ to depths of $10 \mathrm{~km}$. As inferred from work by Diment, ${ }^{18} \sim 5 \%$ of the total U.S. land area may have rock with geothermal gradients of $40^{\circ} \mathrm{C} / \mathrm{km}$ or more. Conservatively, one could assume that over $33 \%$ of the U.S. land is characterized by above average heat flow and gradients ranging from 30 to $36^{\circ} \mathrm{C} / \mathrm{km} .{ }^{2} \mathrm{R}$. $\mathrm{M}$. Potter collected oil and gas well temperaturedepth data from the American Association of Petroleum Geologists and recent estimates by Costain and associates for the Atlantic coastal plain to produce a preliminary gradient map for the U.S., shown in Fig. 8. ${ }^{21,22}$

The large blank areas represent regions without extensive oil and gas exploration data and do not necessarily correspond to low-gradient areas. A cursory examination of the map does illustrate two very important facts. High gradients are not exclusively located in the Western U.S., nor are they just associated with hydrothermal resource areas (KGRA's) such as The Geysers region in northern California or the Imperial Valley region of southern California. For example, note the high-gradient areas on the Atlantic coast, in the Illinois and Indiana area, and in the South Dakota and Nebraska area.

Of similar importance to temperature gradients are the physical and chemical properties of the formation itself. For example, basement or crystalline rock and deep sediments will have widely different permeabilities, porosities, and chemical reactivities to water and will obviously affect the HDR concept used and, therefore, affect costs. An extensive evaluation of potential HDR sites is now under way at LASL. This will be based on improvements to the gradient data base provided by the USGS resource assessment program.

\subsection{Reservoir and Plant Engineering}

Several engineering issues are related to the reservoir and the surface conversion plant influence costs.

- reservoir lifetime and size

- reservoir flow capacity
- heat rejection conditions

- plant design temperature

- pressure losses and pumping requirements

- geothermal fluid chemistry

The first four issues reflect directly on reservoir and plant performance discussed earlier. For example, fracture size (A) and system flow capacity $\left(m_{w}\right)$ attainable will depend on success in developing operational reservoirs for a wide variety of in situ conditions. These reservoirs may encompass formation of large fractures, multiple parallel fractures, remedial refracturing, and thermal stress cracking enhancement. Consequently, in order to examine the impact of finite reservoir size and flow capacity, thermal drawdown rates are established for specified reservoir conditions using equations presented in the reservoir performance section. For any given set of resource and power plant conditions, Milora and Tester were able to show that an optimal plant design temperature exists. ${ }^{18}$ The selection of the optimum becomes more complex as reservoir temperature declines. One reason for this is the severe cycle performance penalty experienced by operating the plant at below design conditions. The primary effect of a reduced wellhead or reservoir temperature is a reduction in cycle and utilization efficiency. For example, a power output decline estimate is given in Fig. 9, where the relative power $f\left(T_{d}\right)=P(T) / P\left(T_{d}\right)$ is represented as a function of the fractional source temperature decline.

If a conventional steam flashing cycle were used, it would be very difficult to extract work economically from the turbine at an exhaust temperature approaching $27^{\circ} \mathrm{C}$ because the density of saturated steam at this temperature is so low that extremely large turbine blade areas would be required. Furthermore, in many parts of the U.S. it may not be possible to operate at these low heat rejection temperatures. For example, in the Imperial Valley area of California $49^{\circ} \mathrm{C}\left(120^{\circ} \mathrm{F}\right)$ is a more appropriate design condensing temperature. For these cases, the advantage of nonaqueous, high vapor density working fluids in binary cycles over steam flashing cycles is diminished. Another point concerning heat rejection has to do with the effect of seasonal and diurnal variations in ambient temperature on cycle performance. Conventional practice in the power generation industry is to design the plant capacity for the "worst day" conditions. Because of the smaller size of geothermal units $[<100 \mathrm{MW}(\mathrm{e})]$, it might be desirable to operate with 


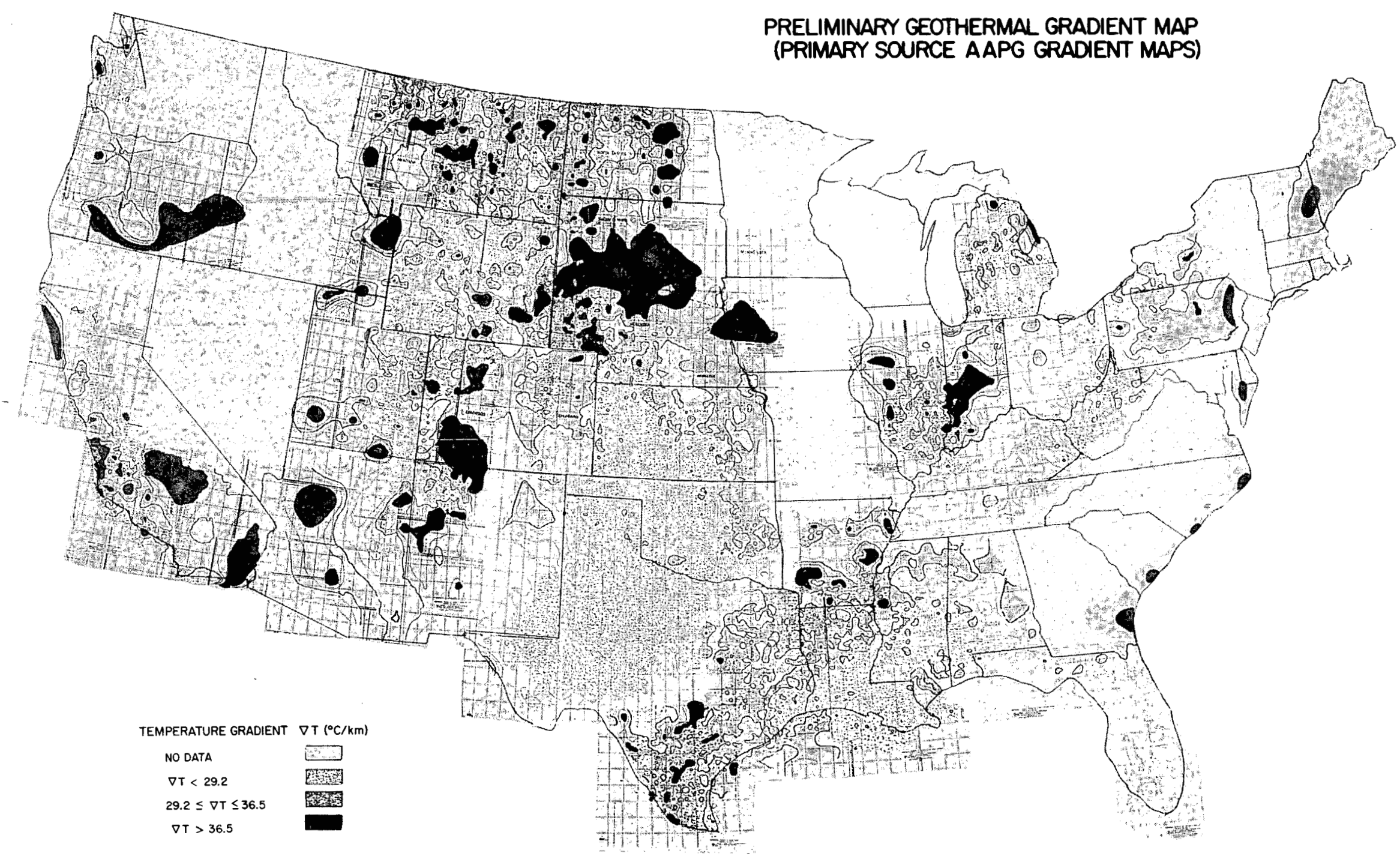

Fig. 8.

Preliminary geothermal gradient map showing three ranges of gradients. Map prepared by R. M. Potter. ${ }^{21}$ 


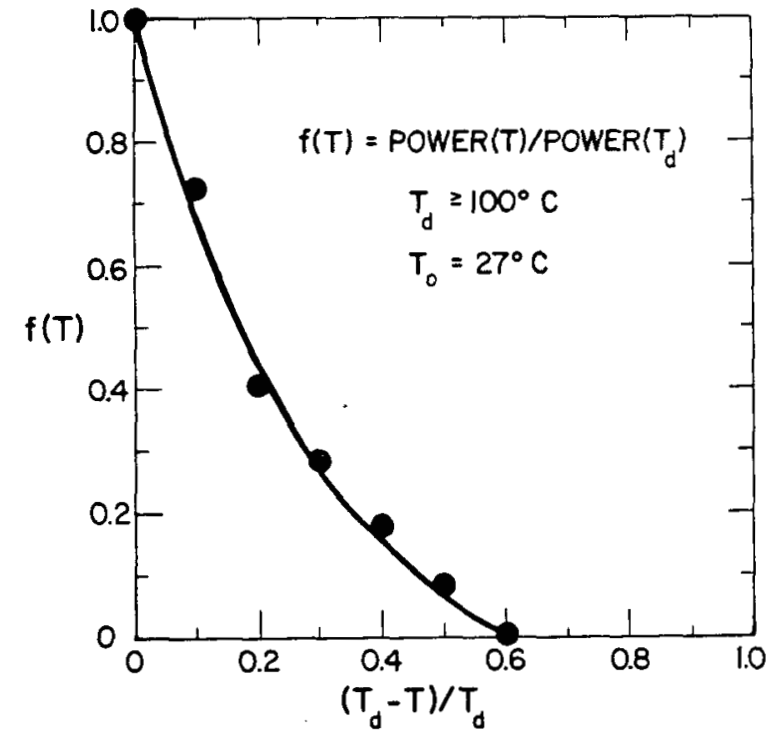

Fig. 9.

Fractional power decline $f(T n)$ as a function of fractional source temperature drop from the design temperature $T_{\mathrm{d}}$.

a floating power output. Khalifa has shown that with a seasonal variation of $\pm 15^{\circ} \mathrm{C}$, the power loss associated with an increase in ambient temperature is fully compensated by the power gain associated with an equivalent decrease in ambient temperature.$^{28}$ For this fluctuation of $\pm 15^{\circ} \mathrm{C}$, Khalifa estimates that the power output would vary by $\pm 32 \%$. Nonetheless, because of the inherently low efficiency of geothermal cycles, in general, when operating with pressurized water below $300^{\circ} \mathrm{C}$, a premium is placed on optimizing cycle performance by using lower ambient temperatures when and where environmental conditions permit. For example, with a $200^{\circ} \mathrm{C}$ liquid resource, a decrease in condensing temperature from $49^{\circ}$ to $27^{\circ} \mathrm{C}$ increases the potentially available work by as much as $40 \% .^{18}$

A preliminary estimate of the geothermal fluid flow requirements is given in Fig. 10 for a binary fluid cycle operating with a $10^{\circ} \mathrm{C}$ approach temperature in the primary heat exchanger and condenser and a $27^{\circ} \mathrm{C}$ condensing temperature.

Pressure losses throughout the system will affect pumping requirements and, therefore, costs. These will include frictional losses in piping, well casing within the fracture itself, and form-drag losses at the entrance and exit regions of the fracture in each wellbore." These losses are partly offset by the

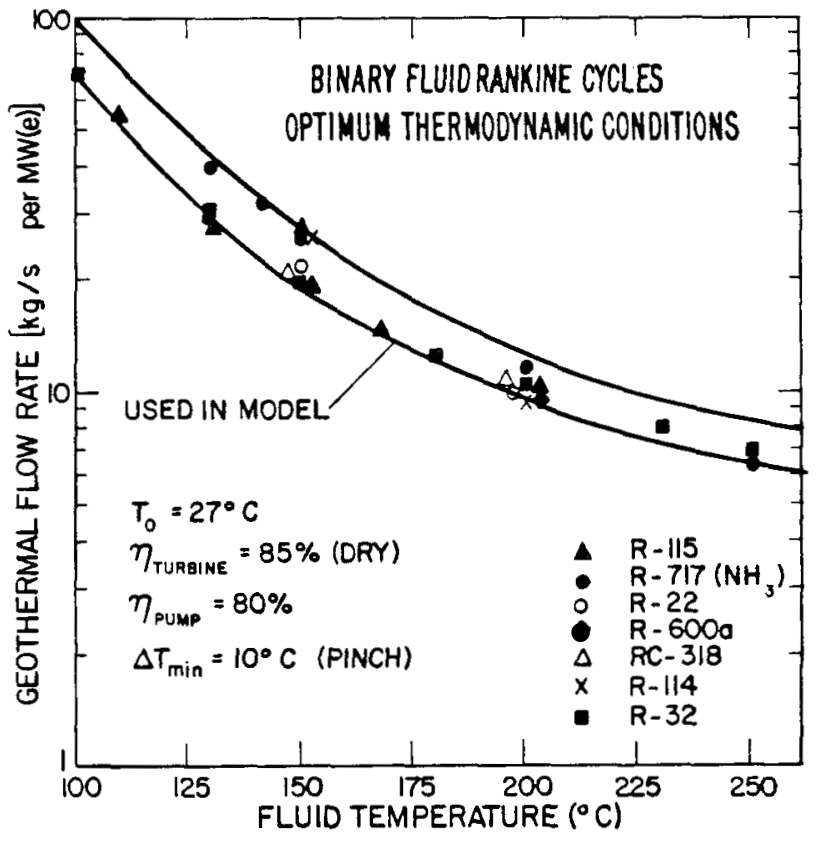

Fig. 10.

Geothermal flow rate requirements per megawatt as a function of fluid temperature.

buoyancy gain between the cold injection and hot recovery wellbores. The impedance within the fracture system and the exit and entrance regions will probably have the largest impact since it may be partially controlled by formation properties and fracture system geometry as we have seen at the LASL Fenton Hill test site. ${ }^{1,3,4}$ Frictional losses in the surface and downhole piping can, of course, be minimized by increasing diameters.

In some cases the chemical composition of the geothermal fluid may strongly influence the cost of surface and subsurface components. As reservoir temperatures increase by drilling deeper, general increases in mineral solubility and reaction rates are observed. Consequently, the potential for corrosion and silica and carbonate scaling, in particular, will increase as rock-water temperatures rise. However, this effect will be site and formation specific, and its economic impact evaluated separately in each case.

\subsection{Economic}

A complete evaluation of HDR technology as it relates to electricity production must necessarily 
overlay cost accounting and financial features upon the resource and engineering dimensions noted above. This section discusses the primary aspects of capital and operating costs, revenues, interest rates, taxes, and other financial issues as they are formulated in the computer model. The model itself was then used to determine the best management strategy for an HDR system and to evaluate its commercial attractiveness. The model addresses both of these issues because an HDR system has a number of important design and operating choices that can be selected to optimize return on investment. The correct basis for evaluating the commercial potential of an HDR system, then, is closely related to the optimal design and management of that system.

The model employed in this research requires as input basic information about the HDR system under consideration. It then determines the optimal time path of management decisions for this system, where optimal is defined as that management strategy that maximizes the present value of aftertax return $(\phi)$ to the operators. This objective is expressed mathematically in Eq. (3) as

$$
\begin{aligned}
& \operatorname{maximize} \Phi=\sum_{n=1}^{N}\left[\sum_{t=1}^{\tau}\left(R_{n, t}\right)(1+r)^{-t}\right] \\
& -\left\{c_{s}+\sum_{n=1}^{N} c_{d}(1+r)^{-\tau(n-1)}\right. \\
& +0.51\left[\sum_{n=1}^{N} c_{d}(1+r)^{-\tau(n-1)}-\frac{c_{d}}{(1+r)^{\tau N}}\right] \\
& \left.-0.51 C_{s}\left[\frac{(1+i)^{\tau N}}{(1+r)^{\tau N}}-\frac{1}{(1+r)^{\tau N}}\right]\right\}
\end{aligned}
$$

where

$\mathrm{N}=$ the number of decision periods over the assumed life of the HDR system,

$\tau=$ the number of years in a decision period,

$r \quad=$ the opportunity cost of capital (real rate of return), $\mathrm{i}=$ the real debt rate of interest,

$R_{n, t}=$ revenues net of revenue tax and operating cost for the $t^{\text {th }}$ year of the $\mathrm{n}^{\text {th }}$ decision period (1978 dollars),

$\mathrm{C}_{8}=$ surface plant costs (1978 dollars) discounted to present value at year 0 (start of plant operation), and

$\mathrm{C}_{\mathrm{d}} \quad=$ drilling costs (1978 dollars).

This equation is structured so the system is examined at each decision period. After exploring the ramifications of each management option for every state of the system, it then selects the option that maximizes the objective function. By doing this for all decision periods over the life of the system, it arrives at a determination of the optimal time path of such decisions and, hence, the most economic way of operating the system.

In this formulation, the revenues and various costs are each discounted to the beginning of electricity production or plant operation ("the present") by an appropriate discount rate and then the difference between revenues and total costs is calculated. The present discounted value of revenues is the doublesummed term just to the right of the equality in Eq. (3). The present discounted value of costs is in braces on the right-hand side of the equation and is composed of separate terms for surface costs, drilling costs, income taxes on equity, and income tax deduction credits on interest payments to debt holders. As implemented in our model, however, the composition of the terms presented in Eq. (3) is much more elaborate than this description alone would suggest, and details are presented below for the individual terms of Eq. (3).

The reader should appreciate at the outset that all costs and revenues in the model are transformed into "real" 1978 dollars. These are dollars that, no matter when they are received or spent, have the same real purchasing power as the dollar does in 1978. The use of this concept allows one to automatically determine the impacts of general price inflation or deflation from the analysis. This approach, however, does assume that there is no change in the real relative 1978 prices of the purchased inputs of HDR technology relative to its marketed output, electricity. What follows is a discussion of the major financial components contained in the model. 
6.3.1. Revenues. The revenues received by the HDR plant owner are $R_{n, t}$ of Eq. (3). These revenues are the product of average annual electricity production in $\mathrm{kWh}$ and the adjusted price(p) in $\$ / \mathrm{kWh}$. Annual production is calculated by Eq. (4),

$\mathrm{Q}_{\mathrm{n}}=\mathrm{f}\left(\mathrm{T}_{\mathrm{n}}\right) \cdot \mathrm{F}_{\mathrm{n}} \cdot \mathrm{kW}(\mathrm{e}) \cdot 8760 \cdot 0.85 \cdot \mathrm{Z}_{\mathrm{n}}$,

and $R_{n, t}=p \cdot Q_{n}$,

where

$\mathrm{Q}_{\mathrm{n}} \quad$ = average annual quantity of electricity produced in a decision period in kilowatt hours,

$f\left(T_{n}\right)=$ the average efficiency associated with operating a plant in period $\mathrm{n}$ at a given fluid temperature different from the design temperature (see Fig. 9),

$\mathrm{F}_{\mathrm{n}} \quad=$ the average efficiency factor associated with operating a plant in period $\mathrm{n}$ at a given flow rate different from the design flow rate,

$\mathrm{kW}(\mathrm{e})=$ the rated kilowatt-electric capacity of the plant,

$\mathrm{p} \quad=$ electricity busbar selling price in dollars per kilowatt hour,

$8760=$ the hours per year,

$0.85=$ the estimated load factor for the facility, and

$\mathrm{Z}_{\mathrm{n}} \quad=$ a load factor to account for plant shutdown during redrilling.

Busbar electricity prices are adjusted to include two costs of production that can be subracted from revenues before the optimization search begins. First, the operating and maintenance cost of production is estimated to be $\$ .0013 / \mathrm{kWh}$ produced ${ }^{13}$ and is simply subtracted from the estimated real busbar price of electricity in 1978 dollars assumed at specific values ranging from 2 to $10 \mathrm{~d} / \mathrm{kWh}$. The typical power plant is fully automated for operation as a base load unit. Experience at The Geysers (Ref. 15) and other facilities around the world has shown that 2 or 3 people per shift can operate a plant of 100-MW(e) capcity. The second cost adjustment reflects the effect of a revenue tax on electricity. This tax is set at $2.5 \%$ of the busbar price* and, once

*This is the current revenue tax rate paid by the Public Service Company of New Mexico. calculated, is also subtracted from the estimated busbar price. The price per kilowatt hour is used with the production estimate of Eq. (4) to determine annual net revenues after operating and maintenance costs and revenue taxes have been deducted.

Note that structuring the model in terms of real dollars, as in Eq. (3), has introduced an important, implicit assumption regarding the behavior of electricity prices. This assumption is that the nominal price of electricity increases to keep pace with general price inflation.

6.3.2. Surface Plant Costs. Surface plant construction costs were adapted from Milora and Tester. ${ }^{18}$ These costs are estimated to be a decreasing linear function of design temperature between 100 and $300^{\circ} \mathrm{C}$ and directly proportional to capacity, which is above $50 \mathrm{MW}(\mathrm{e})$ as shown in Eq. (5). Milora and Tester's original estimation equation was then scaled up by $10 \%$ to allow for inflation to 1978 prices.

$\mathrm{C}_{\mathrm{p}}=\mathrm{kW}(\mathrm{e})\left(976.9-2.146 \mathrm{~T}_{\mathrm{d}}\right) 100 \leq \mathrm{T}_{\mathrm{d}} \leq 300^{\circ} \mathrm{C}$,

where $C_{p}$ is the cost of the surface plant in 1978 dollars.

Although the calculational methods concerning how Eq. (5) was empirically developed cannot be presented here because of space limitations, several important features are described. First, a factored estimate approach was used where direct and indirect cost multiplying factors were combined with the total purchased cost of major equipment associated with power conversion to arrive at an estimate of the fixed capital investment. For the binary fluid cycle considered, this equipment included a primary heat exchanger, desuperheater/condenser, wet or dry cooling towers, turbine, generator, and feed pump. The direct cost factor covers the costs of plant piping, buildings and structures, instrumentation, and equipment installation. The indirect factor covers engineering fees, contingency, escalation during construction, and environmental impact. The application of these cost factors resulted in the installed cost of the surface plant as 2.8 times the purchase cost of the major equipment. Plant capacities in the 50- to $100-\mathrm{MW}(\mathrm{e})$ range were used. Heat exchange equipment was 
costed using empirical correlations, which gave component cost per unit surface area as a function of material of construction, and shell and tube side pressures. Turbine and pump costs were also generated empirically, based on such things as number of stages, exhaust end pitch diameter, casing pressure, bladetip speed, and materials of construction..$^{\text {19 }}$

The cost equation given for the plant was obtained by averaging a number of binary fluid cycle case studies with geothermal fluid source temperatures at the primary heat exchanger varying from 100 to $300^{\circ} \mathrm{C}$. For each fluid a number of heat rejection temperatures $\left(27,37\right.$, and $49^{\circ} \mathrm{C}$ ) and designs were also pursued; these included dry and wet cooling towers, direct air-cooled desuperheater/condensers and once-through fresh and sea-water condensers. Optimal operating conditions minimized the combined surface plant and reservoir development investments. Parameters that were varied included primary heat exchanger and condenser approach temperatures and cycle operating pressure from subcritical to supercritical operation.

Equation (5) was constructed as a guide to show the effects of temperature on surface plant costs. In general, it should be used cautiously, keeping in mind that surface plant costs can vary easily by $\pm 30 \%$ using any number of design possibilities. Once a specific site has been selected, more specific plant designs can be considered.

The power plant costs were then distributed over an estimated 5-yr construction period: $10 \%$ cash outlay in the first year, $17 \%$ in the second year and $24.33 \%$ in the third, fourth, and fifth years of construction. In keeping with the feasibility criterion, these staggered construction costs were all compounded by the appropriate discount rate to the beginning of plant operations (year 0 ).

\subsubsection{Leasing, Royalties, Exploration, and Site} Development Costs. For reasons of convenience and computational efficiency, the $\mathrm{C}_{\mathrm{s}}$ term of Eq. (3) contains several other costs in addition to the present discounted value of the distributed plant construction costs $\mathrm{C}_{\mathrm{p}}$. Also included are the present value accountings of exploration, leasing, and site development, which are delineated in Table I. In addition, $\mathrm{C}_{\mathrm{s}}$ includes the present value of property or ad valorem taxes paid annually on one-third of the undepreciated portion of the plant's capital cost $\mathrm{C}_{\mathrm{p}}$, and a working capital charge equal to $10 \%$ of the present discounted value of the plant cost.

No royalty charges are included as costs in the program. We assume that the HDR well sites are

\section{TABLE I}

\section{ESTIMATED EXPLORATION, LEASING, AND DEVELOPMENT COSTS FOR A HOT DRY ROCK POWER PLANT}

\begin{tabular}{c}
$\begin{array}{r}\text { Years to Start } \\
\text { of Production }\end{array}$ \\
\hline 9 \\
9 \\
8 \\
7 \\
7 \\
6
\end{tabular}

\section{Type of Activity}

Power plant site purchase

Leased well site (32 acres per pair of wells)

Geophysical surveys for site reconnaissance

Geophysical surveys for site selection

Shallow exploration drilling (5 holes)

Deep evaluation drilling
Cost in Thousands

(1978 dollars)

$\$ 125$

$\$ 0.292 /$ pair of wells/yr

$\$ 131$

$\$ 131$

$\$ 262$

$\$ 2360$

'Based on a $\$ 7.00 /$ acre (1976 dollars) lease cost figure per acre estimated by Altseimer ${ }^{24}$ and from data supplied by Grieder. ${ }^{26}$ 
located on privately owned land and the lease costs are paid in lieu of production royalties to the private owner. We believe the least costs are reasonable because the production of fluids by an HDR system disturbs very little of the surface area, allowing the land surface to be kept in productive use, and because the broad availability of the resource fosters a "buyers market." This is in contrast to the present condition for natural hydrothermal systems located on Federal (or state) lands where the royalty corresponds to $10 \%$ (or $10-15 \%$ ) of gross revenues. As Rex points out,this may amount to over 100 million dollars (1978 dollars) for a 100-MW(e) plant assuming a 30 -yr lifetime and a $2.5 \mathrm{~d} / \mathrm{kWh}$ busbar price with a $6 \%$ annual inflation rate. ${ }^{26}$

6.3.4. Drilling Costs. The drilling cost component of Eq. (3), $C_{d}$, includes the following costs: drilling, rig mobilization-demobilization charges, actual drilling or redrilling expenses, and the cost of constructing the fluid gathering system.

Based on current experience for continent drilling, the rig mobilization-demobilization charge may be approximated by a linear step function of the completed hole depth since deeper holes require larger capacity rigs, as expressed in the following equation.

$$
\mathrm{M}=\left[120000 \cdot \operatorname{IP}\left(\mathrm{D}_{\mathrm{f}} / 2000\right)\right]+60000 \mathrm{D}_{\mathrm{f}} \geq 2000
$$

$M=96000$

$$
\mathrm{D}_{\mathrm{f}}<2000 \text {, }
$$

where

$\mathrm{M}$ = the rig mobilization-demobilization charge in 1978 dollars,

$\mathrm{D}_{\mathrm{f}} \quad$ = final hole depth $\mathrm{m}$, and

$\operatorname{IP}()=$ integer part of () .

The initial drilling charge employed by the model is an exponential function of depth and is proportional to the number of pairs of wells that are drilled and completed. The exponential function is based upon an extrapolation of oil and gas well costs scaled to observations on costs for several geothermal wells. Assuming a constant geothermal gradient, initial reservoir depths were calculated from a specified design temperature. Milora and Tester generated the empirical cost function as given in the following equation.

$$
C_{w}=154.55 D_{f} \exp \left(0.00039 D_{f}\right) \text { in } 1978 \text { dollars . }
$$

The direct drilling costs $\mathrm{C}_{\mathrm{w}}$ include a $20 \%$ inflation over 1976 values quoted by Milora and Tester. ${ }^{13}$ The drilling costs given are estimates for completed and cased holes of $23-$ to $30-\mathrm{cm}$ (9- to 12-in.) diameter in hard, hot, crystalline basement rock, and they assume a constant ratio of $\sim 2$ between the cost of a hot dry rock well and an oil or gas well to the same depth from $1.10 \mathrm{~km}$. As Altseimer points out, this may be an overly pessimistic assumption because the problems with drilling deep wells in general (large rigs, long pipe trip times, etc.) will probably outweigh the difference between drilling in basement vs sedimentary rock. ${ }^{24}$ In fact, with proper drill bit design and optimized drilling procedures, reasonable penetration rates and bit lifetimes have been observed in drilling LASL's two deep holes at Fenton Hill. ${ }^{8}$ This, coupled with inherent stability of basement formations and the ability to drill with water rater than mud, will no doubt cause a convergence of the hot dry rock and oil and gas well costs at depths over $4 \mathrm{~km}$.

For redrilling wells, costs are calculated as the difference between drilling to the final depth and drilling to the initial depth using Eq. (7) with the appropriate rig mobilization-demobilization charge added. This, of course, assumes that the redrilling operation experiences the same order of difficulties as the initial drilling effort. The model also assesses additional drilling costs as a function of the number of fractures created in the neighborhood of the final well depth in any period in which drilling or redrilling occurs. It simply adds sufficient additional drilling length to ensure $50 \mathrm{~m}$ of horizontal separation between fractures.

The cost of the piping and equipment for the fluid gathering system is calculated as directly proportional to the linear footage required to make piping connections among the corners of an array of equilateral triangles. This spatial array was selected because it minimizes the piping distances subject to the constraint of a constant well separation with a centrally located power plant.

The sum of all three well-related costs are adjusted in the model by a 1.13 contingency factor, which reflects the uncertainties associated with any drilling operation. Many may argue that this is low for such a high-risk business as drilling. Our position is that the costs given in Eqs. (6) and (7) represent costs based on current drilling experience. In order to fully explore the ramifications of widely varying drilling costs, a compete sensitivity analysis should 
be conducted for a range of $50 \%$ lower to $200 \%$ higher costs. This will be reported in a later report.

6.3.5. Income Taxes. Income taxes are incorporated into the model by way of the last two terms in Eq. (3). The first of these terms taxes the equity returns on capital at a combined state-Federal income tax rate of $51 \%$ and adds it as a cost of doing business. This tax rate corresponds to an effective tax rate for a Federal corporate income tax rate of $48 \%$ and a state corporate income tax rate of about $5.8 \%$. The effective combined rate is $51 \%$ because state taxes are deductible expenses on the Federal return. The second term calculates the interest payments necessary to finance corporate debt and reduces the tax obligation by $51 \%$ of this amount. It thus reflects the fact that this type of expense is deductible from revenues for the purpose of computing taxable income.

\subsubsection{Appropriate Rates for Discounting.} Equation (3) indicates that the choice of $r$ and $i$ values are pivotal in determining economic feasibility in our model. The discount rate $r$ is meant to represent the real after-tax opportunity cost of capital to the firm. This might be thought of as the minimum equity rate of return. The debt rate of return $i$ is meant to represent the cost of borrowing the debt portion of the capital investment. For convenience we have assumed that the surface costs $\mathrm{C}_{8}$ are $100 \%$ debt financed and the drilling costs $\mathrm{C}_{\mathrm{d}}$ are $100 \%$ equity financed. For an integrated investment, this corresponds to roughly a $0.5 \mathrm{debt} /$ equity ratio in most of our model runs.

The choice of a particular $r$ and $i$ in these model runs is based upon the assumption that HDR technology has been proved to the point where utilities are willing to invest in an integrated system of completed wells, fluid distribution system, and surface power plant. Such an assumption runs contrary to the current practice in producing electricity from vapor- or liquid-dominated fields. In these situations private firms (typically oil companies) produce the geothermal fluid and then sell it directly to a public or private utility, which uses it to generate electricity.

Two major considerations, however, have prompted us to treat the system as wholly owned by a public or private utility. First, our model demonstrates the distinct economic advantages of managing the system as a unit; for example, matching the electric plant design conditions to the managed resource with controlled flow rates. Second, we believe that current arrangements are to a large extent the result of the risky nature of contemporary geothermal ventures. By assuming that the technology has been "proved", we are in effect reducing the financial risk and eliminating a major factor that led to the current institutional division of functions between producer and power generator.

In general, utilities are currently paying a nominal debt interest rate of approximately $9 \%$ and a nominal equity rate of return of approximately $12 \%$. By assuming that these investors anticipated a general future rise in prices of $6 \%$ a year, one can deduce that the real rates of return required by these investors were 3 and $6 \%$. These rates were selected for the base case runs of the model with the higher equity rate of return applied to drilling costs and the lower debt interest rate to power generation costs. The effects of higher real rates of return were also explored parametrically. These higher rates of return and interest rates may approximate a situation where HDR technology is still relatively new and investors require a risk premium to compensate them for the uncertainty of the outcome. These rates may reflect somewhat higher risks associated with the surface plant, but most certainly higher risks related to the reservoir.

\section{METHOD OF ANALYSIS}

To summarize, we are concerned with evaluating the present value of net (after-tax) profits for an HDR electric generating facility as these profits vary with the geothermal temperature gradient $\nabla \mathrm{T}$ and the design well flow rate $\dot{\mathrm{m}}_{d}$ for a specified busbar electricity price.

For constant power output with $\dot{\mathrm{m}}_{\mathrm{d}}$ constant, low gradients necessitate deeper drilling, and also higher drilling costs and lower profits. For a given $\nabla T$, lower well flow rates imply (a) higher drilling costs because of increases in the number of HDR wells required to satisfy the generating plant's design flow rate, and (b) somewhat lower individual well costs because of the fewer fractures (per HDR reservoir) required to minimize temperature drawdown. At issue then is the question: For a given reservoir design, under what flow rate conditions and for what values 
of $\nabla \mathrm{T}$ might HDR-produced electricity be commercially competitive in the U.S.? Answers to this question have important implications for required reservoir designs so that these economically viable flow rates can be accommodated with acceptable temperature drawdown (see Reservoir Performance, Sec. 3 above).

In addition, the geothermal gradient has an impact on the choice of optimal surface plant design temperatures. Because of the exponential dependence of drilling costs on depth vs the linear decline of surface plant costs with increasing reservoir temperature, one would expect that shallower reservoirs with lower design temperatures would result in higher profits when geothermal gradients are lower. The method used here for determining the present value of net profits associated with alternative combinations of $\dot{m}_{d}$ and $\nabla T$ involves the solution of the intertemporal optimization model described above. The variables subject to control in the model are, first, the periodic well flow rate $\dot{m}$, which varies in the interval $0.8 \dot{\mathrm{m}}_{d} \leq \dot{\mathrm{m}} \leq \dot{\mathrm{m}}_{\mathrm{d}}$; second, initial drilling depths for the HDR reservoirs, and periodic redrilling. Parameters (and parameter values) used in the model include installed capacity [50 MW(e)], design temperature for the electric generating plant $\left(160^{\circ} \mathrm{C}\right.$ ), reservoir size (varied with $\dot{\mathrm{m}}$ so as to result in negligible temperature drawdown), and the economic parameters described in Sec. 6. A 30-yr plant life is assumed. For our purposes, a selling price at the busbar, exclusive of transmission and distribution costs of electricity, is set at either 3 or $4 \mathrm{~d} / \mathrm{kWh} ; \dot{\mathrm{m}}_{\mathrm{d}}$ and $\nabla \mathrm{T}$ are varied parametrically. Table II lists these base case conditions.

Given values for $\nabla \mathbf{T}, \dot{\mathrm{m}}_{\mathbf{d}}$, and the price of electricity at the beginning of each decision period (a "decision period" in this case is a five-yr time inter$\mathrm{val}$ ), the model calculates the present value of present and future profits associated with all combinations of $\dot{m}$ and drilling (and redrillings) depths, and chooses the combination that maximizes the profits as given by Eq. (3). Given that all costs, taxes, insurance, and accumulated interest charges are included in the model, a zero value for the objective function Eq. (3) implies a break-even cost of $3 \mathrm{~d} / \mathrm{kWh}$ (or $4 \mathrm{~d} / \mathrm{kWh}$ when the $4 \mathrm{~d} / \mathrm{kWh}$ price is used). A negative objective function would imply a breakeven cost greater than $3 \mathrm{~d} / \mathrm{kWh}$ (or $4 \mathrm{~d} / \mathrm{kWh}$ ), and a positive value would imply a break-even cost less

\section{TABLE II}

\section{BASE CASE PARAMETER VALUES USED TO EVALUATE HOT DRY ROCK ENERGY FOR THE PRODUCTION OF ELECTRICITY}

\author{
Life of the System $=30 \mathrm{yr}$ \\ Length of Time in a Decision Period $=5 \mathrm{yr}$ \\ Electric Plant Capacity $=50 \mathrm{MW}(\mathrm{e})$ \\ Radius per Fracture $=300 \mathrm{~m}$ \\ Maximum Well Flow Rate $(\dot{\mathrm{m}})=75 \mathrm{~kg} / \mathrm{s}$ \\ Fractures per Pair Wells ${ }^{a}=12$ \\ Horizontal Fracture Spacing $=50 \mathrm{~m}$ \\ Geothermal Gradient $=40^{\circ} \mathrm{C} / \mathrm{km}$ \\ Busbar Price of Electricity $=3 \mathbf{d} / \mathbf{k W h}$ \\ Real Cost of Equity Capital ${ }^{b}=6 \%(12 \%$ nominal $)$ \\ Real Cost of Debt Capital ${ }^{\mathrm{b}}=3 \%$ ( $9 \%$ nominal) \\ Operation and Maintenance Costs $=0.13 \mathrm{~d} / \mathrm{kWh}$ \\ Revenue $\operatorname{Tax}=0.07 \mathrm{~d} / \mathrm{kWh}$ ( $2.5 \%$ of busbar price) \\ Joint Federal and State Income Tax Rate $=51 \%$
}

\begin{abstract}
The number of fractures were selected to ensure that reservoir temperature drawdown does not significantly affect system efficiency. This would be equivalent to assuming that sufficient heat transfer area (by means of thermal stress cracking and/or large enough fractures) existed to maintain geothermal fluid temperatures within $10 \%$ of their original design value.

'These capital costs are referred to as "real" because they are exclusive of the investors' anticipated rate of general price inflation.
\end{abstract}

than 3 or $4 d / k W h$. A complete specification of this dynamic programming model is given by Cummings et al. ${ }^{27}$

The issue of what busbar price is required to reach economic feasibility is certainly an important one. Because of the mathematical structure of the model, however, it must be determined indirectly. In the intertemporal model described, the busbar price of electricity $p$ is specified as a parameter in the revenue term [Eq. (4)], as are geothermal gradient $\nabla \mathrm{T}$ and design flow rate $\dot{\mathrm{m}}_{\mathrm{d}}$ before the dynamic programming algorithm begins computation. When the net profits or benefits from Eq. (3) equal zero, this break-even point is reached for a given set of conditions including price, $\left(p=p^{*}\right)$. The price $p^{*}$ is therefore referred to as the "breakeven" price. At this point, the revenues produced from the sale of electricity are enough to just cover all costs, including interest payments of debt, return on equity 
and income, and ad valorem taxes, where both the revenues and costs are evaluated in terms of present discounted value.

\section{ANALYSIS OF RESULTS}

Results from the model using prices of 3 and $4 \mathrm{~d} / \mathrm{kWh}$ are given in Figs. 11 and 12, respectively. With the $3 \mathrm{~d} / \mathrm{kWh}$ price (Fig. 11) and a $40 \mathrm{~kg} / \mathrm{s}$ well flow rate, the present value of net after-tax profits for an HDR electric generating facility is negative at $-\$ 9.2$ million in areas with gradients of $40^{\circ} \mathrm{C} / \mathrm{km}$. With that same gradient, however, the present value is positive for higher well flow rates, ranging from $\$ 1$ million to $\$ 22.8$ million as $\dot{\mathrm{m}}_{\mathrm{d}}$ increases from $50 \mathrm{~kg} / \mathrm{s}$ to $150 \mathrm{~kg} / \mathrm{s}$.

The data of Fig. 11 can be generalized as they relate to the commercial feasibility of HDRproduced electricity with reservoirs designed for negligible temperature drawdown using the assumptions described earlier. The main conclusions follow.

- In areas with geothermal gradients of $50^{\circ} \mathrm{C} / \mathrm{km}$ or higher, HDR-produced electricity is commercially feasible regardless of the well flow rate (in the $40-$ to $150-\mathrm{kg} / \mathrm{s}$ range) at busbar costs less than $3 \mathrm{~d} / \mathrm{kWh}$.

- In areas with a geothermal temperature gradient of $40^{\circ} \mathrm{C} / \mathrm{km}$, a well flow rate of $40 \mathrm{~kg} / \mathrm{s}$ would imply a busbar cost in excess of $3 \mathrm{~d} / \mathrm{kWh}$; for flow rates in the range $50-150 \mathrm{~kg} / \mathrm{s}$, HDR-produced electricity would be commercially feasible with busbar costs less than $3 \mathrm{~d} / \mathrm{kWh}$.

- In areas with gradients in the $20-30^{\circ} \mathrm{C} / \mathrm{km}$ range, HDR-produced electricity would result in busbar costs that are higher (most likely, much higher) than $3 ₫ / \mathrm{kWh}$ for all well flow rates in the $40-$ to $150-\mathrm{kg} / \mathrm{s}$ range.

In the case where a busbar selling price for electricity of $4 \mathrm{~d} / \mathrm{kWh}$ is used (Fig. 12), HDRproduced electricity is commercially competitive for all flow rates in areas with gradients of $40^{\circ} \mathrm{C} / \mathrm{km}$ or higher, at busbar costs much less than $4 d / \mathrm{kWh}$. A feasible operation may have $30^{\circ} \mathrm{C} / \mathrm{km}$ gradients with design flow rates at or above $75 \mathrm{~kg} / \mathrm{s}$.

These results can be put in better perspective by comparing the positive net benefits generated at high geothermal temperature gradients with the initial investment in the wells and power plant system. Total surface and drilling costs vary

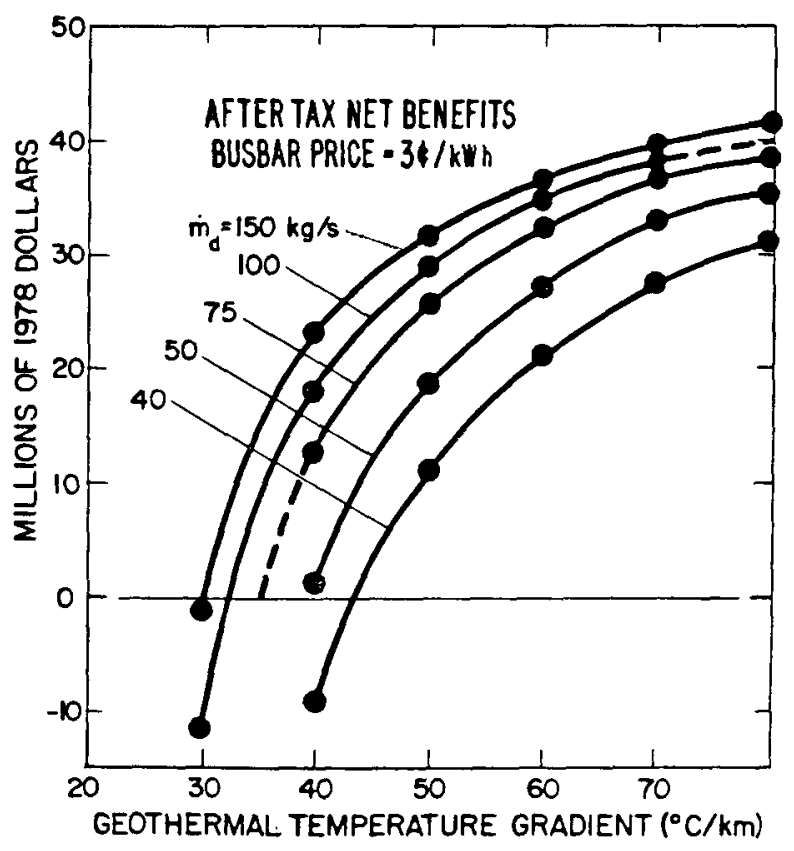

Fig. 11.

Intertemporal optimization model results with a present value busbar price of $3 \mathrm{~d} / \mathrm{kWh}$. Effects of design flow rate $\left(\dot{m}_{\mathrm{\alpha}}\right)$ and gradient on aftertax net benefits shown.

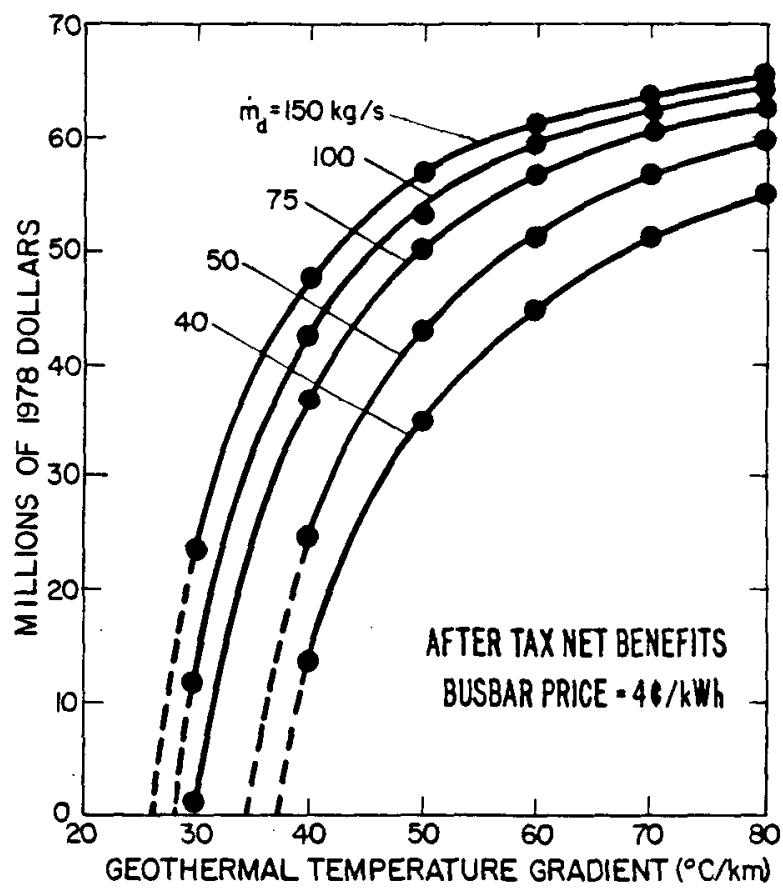

Fig. 12.

Intertemporal optimization model results with a present value busbar price of $4 \mathrm{~d} / \mathrm{kWh}$. Effects of design flow rate $\left(\dot{m}_{\mathrm{a}}\right)$ and gradient on aftertax net benefits shown. 
dramatically, of course, depending on the geothermal gradient and maximum well flow rate, but at $50^{\circ} \mathrm{C} / \mathrm{km}$ gradients, they range between $\$ 106.3 \times 10^{8}$ for a $40-\mathrm{kg} / \mathrm{s}$ maximum flow rate to $\$ 78.1 \times 10^{6}$ for $150 \mathrm{~kg} / \mathrm{s}$ for a $50-\mathrm{MW}(\mathrm{e})$ plant.

Assuming all these costs were incurred at the start of production, they would be equivalent to a nominal combined and installed capital cost for the "fuel" system (wells) and the surface plant of $\$ 2130 / \mathrm{kW}$ for a $40-\mathrm{kg} / \mathrm{s}$ flow rate and $\$ 1560 / \mathrm{kW}$ for a $150 \mathrm{~kg} / \mathrm{s}$ flow rate. At $40 \mathrm{~kg} / \mathrm{s}$ about $40 \%$ of the total is invested in the surface plant and at $150 \mathrm{~kg} / \mathrm{s}$ about $50 \%$. Other economic analyses for hydrothermal systems by Holt and Ghormley ${ }^{28}$ Ramachandrian et al., ${ }^{20}$ Eskesen, ${ }^{80}$ Starling et al., ${ }^{81}$ Schapiro and Hajela, ${ }^{32}$ and Hankin et al. ${ }^{38}$ have shown similar ranges of capital and busbar costs. For $40-150 \mathrm{~kg} / \mathrm{s}$ and electricity prices of $3 \mathrm{~d} / \mathrm{kWh}$, the corresponding net benefits at $50^{\circ} \mathrm{C} / \mathrm{km}$ range from just over $\$ 10 \times 10^{6}$ to just over $\$ 30 \times 10^{6}$, respectively. The net benefits calculated represent a significant portion of the initial investment, especially for the higher flow rate. This means that at high geothermal gradients the real rates of return actually experienced by the equity investors would be considerably in excess of the $6 \%$ rate specified in these runs of the model.These actual rates of return would, of course, be even higher at the busbar price of $4 \mathrm{~d} / \mathrm{kWh}$ (see Fig. 12).

An alternate approach to describing the results may further clarify the feasibility issue. For a given set of resource and reservoir conditions, including formation type, gradient, fracture size, and design flow rate, there exists an optimal management strategy of drilling, redrilling, and operating the plant that will result in a minimum "breakeven" price $\mathrm{p}^{*}$. This corresponds to a condition of "zero net benefits." As described in the previous section, this "breakeven" price would generate revenues just sufficient to cover all costs, including taxes and returns to investors and lenders at the specified real rates. Figure 13 presents this minimum price as a function of the geothermal gradient and the design well flow rate $\dot{m}_{d}$ for the negligible temperature drawdown case $\left(\dot{\mathrm{m}} / \mathrm{R}^{2}=6.67 \times 10^{-5} \mathrm{~kg} / \mathrm{m}^{2} \mathrm{~s}\right.$, Fig. 5). The general trend of decreasing busbar costs with increasing gradients and flow rates is expected because of the improved quality of the reservoir. At higher gradients and flow rates, a busbar price of less than $2 \mathrm{~d} / \mathrm{kWh}$ is sufficient to earn the required $6 \%$ real rate of return.
The effects of equity rate of return and debt in terest rate are shown in Fig. 14, where the breakeven busbar price is plotted as a function of several pairs of values of equity and debt rates with all other parameters as they appear for the base case as given in Table II. Negligible temperature drawdown as shown for the conditions given in Fig. 13 is also as sumed. The actual choice of equity and debt rates is

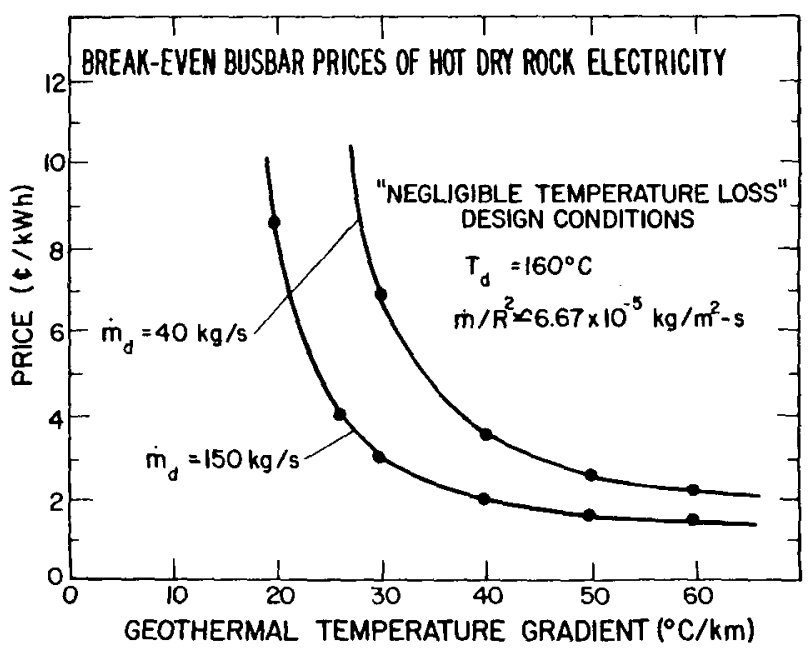

Fig. 13

Busbar price for break-even economic feasibility conditions with negligible reservoir drawdown.

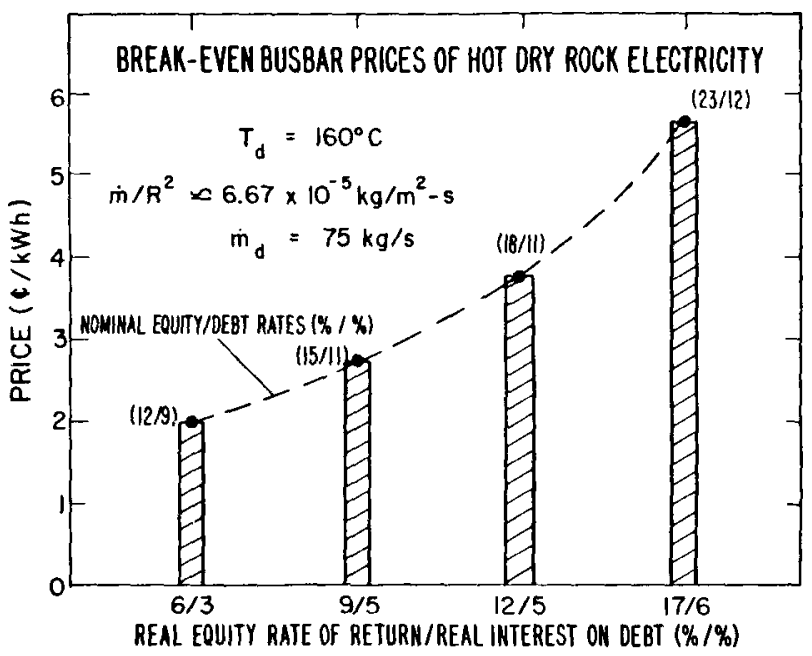

Fig. 14.

The effects of equity rate of return and debt interest rates on break-even busbar price. Equity rate of return applied to drilling costs and debt interest to invested capital in the surface plant. 
somewhat arbitrary, and Fig. 14 is not intended to imply any functional dependence but rather to show the strong influence that these rates have on breakeven conditions.

Finally, it is interesting to note the optimal drilling depths associated with each $\nabla \mathrm{T}-\dot{\mathrm{m}}_{\mathrm{d}}$ combination studied here. These data are given in Table III in the case where $p=3 d / k W h$. As one would expect, the higher the gradient, the shallower is the optimal drilling depth for the same base case design temperature of $160^{\circ} \mathrm{C}$. If we were to recalculate the optimal strategy with a variable design temperature, then design well flow rates and/or gradients increase, the relative capital investment in well drilling decreases, and deeper, hotter reservoirs may be favored. These data bring into sharp focus the relevance of the geothermal gradient for feasible HDR-produced electricity. Total drilling costs per pair of wells, excluding surface piping and contingency factors, fall from $\$ 4.7$ million in the $30^{\circ} \mathrm{C} / \mathrm{km}$ gradient area to $\$ 1.1$ million in the $60^{\circ} \mathrm{C} / \mathrm{km}$ gradient area-a doubling of the gradient results in a $76 \%$ decline in total drilling costs.

\section{CONCLUDING REMARKS}

The analytical results presented here are based on a very limiting set of assumptions as to HDR reservoir parameters and designs. Considerably more ex- perimental and economic research is required before a definitive assessment of the commercial feasibility of HDR-produced electricity can be made. Within this limited context, however, the results provided here suggest grounds for at least guarded optimism as to the possible feasibility of HDR-produced electricity in areas of the U.S. with temperature gradients in the $\geq 40^{\circ} \mathrm{C} / \mathrm{km}$ range, where "competitive" busbar costs are approximately $3 \mathrm{~d} / \mathrm{kWh}$ or higher.

As noted, variations in the reservoir design and operating parameter values, as well as financial and regulatory criteria used in this report could markedly influence the potential competitiveness of HDRproduced electricity. As examples, abnormally high plant costs (caused by poor geofluid quality), higher discount (interest) rates, and, particularly, increased rates of temperature drawdown or reservoir water losses would decrease the relative attractiveness of HDR-produced electricity; however, advances in drilling technology, lower taxes (by way of depletion-type allowances) and allowable deductions for intangible drilling expenses, investment tax credits, and systems designed to accommodate congeneration or process heat plants might well extend the commercial feasibility of HDR to lower gradient areas.

Certainly another factor that will control the rate of commercial development of HDR, or for that matter all geothermal, is the current cost and

\section{TABLE III}

\section{OPTIMAL DRILLING DEPTH (IN METERS) WITH GEOTHERMAL GRADIENT $\left({ }^{\circ} \mathrm{C} / \mathrm{km}\right)$}

$$
\begin{aligned}
\mathbf{p} & =\mathbf{3} \notin / \mathbf{k W h} \\
\mathbf{T}_{\mathrm{d}} & =160^{\circ} \mathrm{C}
\end{aligned}
$$

\begin{tabular}{|c|c|c|c|c|c|c|c|}
\hline \multirow{2}{*}{$\begin{array}{c}\dot{\mathbf{m}}_{\mathrm{d}} \\
\text { Design } \\
\text { Well Flow Rate } \\
(\mathbf{k g} / \mathbf{s})\end{array}$} & \multicolumn{7}{|c|}{$\nabla \mathrm{T}\left({ }^{\circ} \mathrm{C} / \mathrm{km}\right)$} \\
\hline & 20 & 30 & 40 & 50 & 60. & 70 & 80 \\
\hline 40 & - & . & 3900 & 3280 & 2800 & 2460 & 2250 \\
\hline 50 & - & 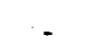 & 3900 & 3280 & 2800 & 2400 & 2150 \\
\hline 75 & - & - & 4000 & 3280 & 2800 & 2400 & 2150 \\
\hline 100 & - & 5070 & 4000 & 3280 & 2800 & 2400 & 2150 \\
\hline 150 & - & 5070 & 4000 & 3280 & 2800 & 2400 & 2150 \\
\hline
\end{tabular}


availability of busbar power from more conventional sources such as coal and nuclear. Partly because of environmental and regulatory restrictions, coal-fired and nuclear plant costs have escalated to a point where $\$ 500-700 / \mathrm{kW}$ for coal and $\$ 1000 / \mathrm{kW}$ or more for nuclear are now commonplace. ${ }^{80}$ To these costs are added the rapidly rising fuel costs for coal and enriched uranium. A reasonable range for busbar prices for $1985-90 \mathrm{might}$ be from 3 to $6 \mathrm{~d} / \mathrm{kWh}$ (in constant 1978 dollars). If busbar costs are at the high end, a considerable incentive for HDR development would exist.

To be expected with new technology, definite statements concerning feasibility must await further development and demonstration. It is encouraging at this point, however, to see that electricity production from HDR resources would seem to be commercially competitive in numerous areas of the U.S. using economic and reservoir parameter values, which are reasonable to many involved engineers and economists. There are no simple answers and each issue must be treated in detail before the question of commercial feasibility for HDR can be settled.

\section{ACKNOWLEDGMENTS}

The authors thank R. M. Potter, A. W. Laughlin, and A. Eddy for their assistance in preparing the HDR resource description. R. Hageman and J. McFarland are also gratefully acknowledged for their contribution to the computational aspects of the model development. We also thank M. Brown, M. Smith, and the late A. G. Blair for their illuminating suggestions in reviewing the manuscript.

\section{REFERENCES}

1. M. C. Smith, R. L. Aamodt, R. M. Potter, and D. W. Brown, "Man-Made Geothermal Reservoirs," in 2nd United Nations Geothermal Energy Symp., San Francisco, California, May 20-29, 1975 (United Nations, 1975), pp. 17811787 .

2. J. W. Tester and M. C. Smith, "Energy Extraction Characteristics of Hot Dry Rock Geothermal Systems," Proc. 12th Intersociety Energy
Conversion Engineering Conf., Washington, DC, August 28-September 2, 1977 (American Nuclear Society, 1977), p. 816.

3. A. G. Blair, J. W. Tester, and J. J. Mortensen, "LASL Hot Dry Rock Geothermal Project," Los Alamos Scientific Laboratory report LA-6525PR (1976) and "Hot Dry Rock Geothermal Energy Development Project," Los Alamos Scientific Laboratory report LA-7109-PR (1978).

4. J. W. Tester, Ed. "Phase I-Energy Extraction Field Test Results from the Fenton Hill Hot Dry Rock Geothermal System, Segments 1-2," Los Alamos Scientific Laboratory report, to be published.

5. R. D. McFarland and H. D. Murphy, "Extracting Energy from Hydraulically Fractured Geothermal Reservoirs," Proc. 11th Intersociety Energy Conversion Engineering Conf., State Line, Nevada,September 12-17, 1976 (American Institute of Chemical Engineers, 1976).

6. F. H. Harlow and W. E. Pracht, "A Theoretical Study of Geothermal Energy Extraction," J. Geophys. Res. 77, (35), 7038 (1972).

7. C. B. Raleigh, P. A. Witherspoon, A. C. Gringarten, and Y. Ohnishi, "Multiple Hydraulic Fracturing for the Recovery of Geothermal Energy (abstract)," E丹S Trans. AGU 55 (4), 4026 (1974).

8. A. C. Gringarten, P. A. Witherspoon, and Y. Ohnishi, "Theciry of Heat Extraction from Fractured Hot Dry Rock," J. Geophys. Res. 80 (8), 1120 (1975).

9. S. Nemat-Nasser, "Thermal Cracks and Their Effects on the Heat Extraction Process," The Technological Institute, Northwestern University, Evanston, Illinois, to be published.

10. S. Nemat-Nasser, "Minimum Spacing of Thermally Induced Cracks in Brittle Solids," The Technological Institute, Northwestern University, Evanistorı, Illinois, to be published. 
11. S. Nemat-Nasser, L. M. Keer, and K. S. Parihar, "Unstable Growth of Thermally Induced Interacting Cracks in Brittle Solids," Earthquake Research and Engineering Laboratory Technical Report no. 77-9-2, Northwestern University, Evanston, Illinois, (September 1977).

12. R. Wunder and H. D. Murphy, "Thermal Drawdown and Recovery of Singly and Multiply Fractured Hot Dry Rock Reservoirs," Los Alamos Scientific Laboratory report LA-7219-MS (April 1978).

13. S. L. Milora and J. W. Tester, Geothermal Energy as a Source of Electric Power (MIT Press, Cambridge, Massachusetts, 1976).

14. H. D. Murphy, "Thermal Stress Cracking and the Enhancement of Heat Extraction from Fractured Geothermal Reservoirs," Los Alamos Scientific Laboratory report LA-7235-MS (April 1978).

15. P. Kruger and C. Otte, Geothermal Energy, (Stanford University Press, Stanford, California, 1973).

16. J. W. Tester, C. E. Holley, and L. A. Blatz, "Solution Chemistry and Scaling in Hot Dry Rock Geothermal Systems," Proc. 83rd National Mtg. of AIChE, Houston, Texas, March 21-25, 1977.

17. D. F. White and D. L. Williams, Eds., "Assessment of Geothermal Resources of the United States-1975, "U.S. Geol. Surv. Circ. 726 (1975).

18. W. H. Diment, T. C. Urgan, J. H. Sass, B. U. Marshall, R. J. Munroe, and A. H. Lachenbruch, "Temperatures and Heat Contents Based on Conductive Transport of Heat," in "Assessment of Geothermal Resources of the United States-1975," U.S. Geol. Surv. Circ. 726 (1975).

19. T. R. McGetchin, Ed., "Hot Dry Rock Geothermal Energy: Status of Exploration and Assessment," Report \#1 of the Hot Dry Rock Assess- ment Panel, ERDA-77-92, Washington, DC (in press).

20. R. L. Smith and H. R. Shaw, "Igneous-Related Geothermal Systems," in "Assessment of Geothermal Resources of the United States1975," U.S. Geol. Surv. Circ. 726 (1975).

21. R. M. Potter, Los Alamos Scientific Laboratory, unpublished results (March 1978).

22. J. K. L. Grover III, J. K. Costain, and A. K. Sinha, "Evaluation and Targeting of Geothermal Energy Reservoirs in the Southeastern United States, Progress Report, Nov. 1, 1976March 31, 1977," Virginia Polytechnic Institute report VPI-SU-5103-3 (1977).

23. H. E. Khalifa, "Effect of Seasonal Variations of Ambient Temperatures on the Performance of Low-Temperature Power Cycles," Brown University report C00/4051-10, CATMEC/19 (June 1978).

24. J. H. Altseimer, "Technical and Cost Analysis of Rock-Melting Systems for Producing Geothermal Wells," Los Alamos Scientific Laboratory report LA-6555-MS (November 1976).

25. R. Grieder, "Economic Considerations of Geothermal Exploration in the Western United States," presented at the Symp. of the Colorado Dept. of Natural Resources, Denver, Colorado, December 1973.

26. R. W. Rex, "The U.S. Geothermal Industry in 1978," presented at the Hot Dry Rock Geothermal Information Conference, Santa Fe, New Mexico, April 19-20, 1978.

27. R. G. Cummings, D. Franklin, and S. Nunn, "Electricity from Hot Dry Rock Geothermal Reservoirs: An Economic Analysis," internal report, Resource Economics Program, University of New Mexico, Albuquerque, New Mexico (August 1977).

28. B. Holt and E. L. Ghormley, "Energy Conversion and Economics for Geothermal Power 
Generation at Heber, California; Valles Caldera, New Mexico; and Raft River, Idaho-Case Studies," Electric Power Research Institute report EPRI ER-301, Palo Alto, California (November 1976).

29. G. Ramachandrian, Ed., "Economic Analysis of Geothermal Energy Development in California," Vol. 1, Stanford Research Institute report ECU 5013, Menlo Park, California (May 1977).

30. J. H. Eskesen, "Cost and Performance Comparison of Flash Binary and Steam Turbine Cycles for the Imperial Valley," Proc. 12th Intersociety Energy Conversion Engineering Conf. Washington, DC, August 28-Semptember 2, 1977 (American Nuclear Society, 1977), Vol. 1, p. 842 .
31. K. E. Starling, L. W. Fish, K. Z. Iqbal, and H. $\mathrm{H}$. West, "The Use of Mixture Working Fluids in Geothermal Power Plants," Proc. 12th Intersociety Energy Conversion Engineering Conf., Washington, DC, August 28-September 2, 1977 (American Nuclear Society, 1977), Vol. 1, p. 850.

32. A. R. Schapiro and G. P. Hajela, "Geothermal Power Cycle Analysis," Proc. 12th Intersociety Energy Conversion Engineering Conf., Washington, DC, August 28-September 2, 1977, (American Nuclear Society, 1977), Vol. 1, p. 857.

33. J. W. Hankin, F. A. Hogue, R. A. V. Cassel, and T. R. Fick, "Effect of Reservoir Temperature Decline on Geothermal Power Plant Design and Economics," Proc. 12th Intersociety Energy Conversion Erigineering Conf., Washington, DC, August 28-September 2, 1977, (American Nuclear Society, 1977) Vol. 1, p. 870. 
